\title{
Branched Poly(ethylene glycol)-Functionalized Covalent Organic Frameworks as Solid Electrolytes
}

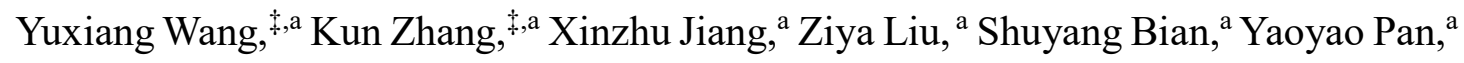
Zhen Shan, ${ }^{a}$ Miaomiao $\mathrm{Wu},{ }^{\mathrm{a}}$ Bingqing $\mathrm{Xu},{ }^{*, a}$ Gen Zhang,a

${ }^{a}$ Key Laboratory for Soft Chemistry and Functional Materials of Ministry of Education, School of Chemistry and Chemical Engineering, Nanjing University of Science and Technology, Nanjing, Jiangsu 210094, China.

These two authors contribute equally to this work.

This work is dedicated to Prof. Susumu Kitagawa (Kyoto University) on the occasion of his $70^{\text {th }}$ birthday.

E-mail: bingqingxu@njust.edu.cn (B.X.); zhanggen@njust.edu.cn (G.Z.) 


\section{Table of contents:}

\section{Materials and general methods}

1.1 Materials

1.2 Characterization

1.3 Ionic conduction measurements

1.4 $\mathrm{Li}^{+}$transference number $\left(\mathrm{t}_{\mathrm{Li}}\right)$ measurements

1.5 Electrochemical performance testing

\section{Synthesis}

2.1 Synthesis of PEG-B1-NHN 2

2.2 Synthesis of PEG-B3-NHN 2

2.3 Synthesis of PEG-B6-NHN 2

2.4 Synthesis of COF-PEG-B1

2.5 Synthesis of COF-PEG-B3

2.6 Synthesis of COF-PEG-B6

2.7 Synthesis of COF-PEG-Bx-Li $(x=1,3,6)$.

\section{Characterization}

3.1 Structural simulation for COF-PEG-Bx $(x=1,3,6)$.

3.2 XRD, Nitrogen adsorption, TGA, IF-TR, DSC and ssNMR

3.3 Ionic conductivity of $\mathrm{COF}_{\mathrm{S}}$

3.4 Activation energy and transference number

3.5 Full cell electrochemical performance tests

3.6 TEM images of COF-PEG-B1

3.7 NMR spectra of COFs

\section{Reference}




\section{Materials and general methods}

\subsection{Materials}

All chemicals and solvents used in the syntheses are reagent grade and used without further purification. 1,3,5-Tris( $p$-formylphenyl)benzeneand and 2,5diethoxyterephthalohydrazide were purchased from Extension and Tensus Biotech, respectively. Polyethylene glycol (PEG, MW=10,000), lithium bis(trifluoromethanesulphonyl)imide (LiTFSI), and ionic liquids (1-butyl-1methylpyrrolidinium bis(trifluoromet-hanesulfonyl)imide, IL) were purchased from Heowns Biochem Technolo-gies LLC. $\mathrm{LiFePO}_{4}$, carbon black and PVDF powders were purchased from Shenzhen Kejing Star Technology Company. All the solvents such as acetic acid, dichloromethane, acetone, N-methylpyrrolidone (NMP) were purchased from Sinopharm.

\subsection{Characterization}

PXRD patterns were collected on a Bruker D8 Advance diffractometer using $\mathrm{Cu}$ $\mathrm{K} \alpha$ radiation. Fourier Transform Infrared spectrum spectrum was measured on a Thermo Fisher Scientific with Universal ATR accessory between the ranges of 4000 to $550 \mathrm{~cm}^{-1}$. Gas adsorption measurement $\mathrm{N}_{2}$ adsorption measurements were performed on a BELSORP II mini, samples were activated at $100{ }^{\circ} \mathrm{C}$ for $12 \mathrm{~h}$ before the measurement. TGA was performed using a NETZSCH STA 449F5 under flowing $\mathrm{N}_{2}$ with $10 \mathrm{~K} \mathrm{~min}^{-1}$ ramp rate from $50{ }^{\circ} \mathrm{C}-900{ }^{\circ} \mathrm{C}$. SEM images were collected using a JSM-IT500HR system. The scanning electron microscopy (TEM) images were collected using a JEM-2100. Differential scanning calorimetry (DSC) was carried out with a Hitachi DSC7020 at the heating rate of $10 \mathrm{~K} \mathrm{~min}^{-1}$. The solid NMR of ${ }^{7} \mathrm{Li}$ and ${ }^{13} \mathrm{C}$ CP-MAS solid-state NMR spectroscopy were recorded on AVANCE III WB 400 $\mathrm{MHz}$ of Bruker.

\subsection{Ionic conduction measurements}

Ionic conduction of electrolytes was tested and evaluated by pressing into pellets, further sandwiched between two stain steels, and assembling into coin cells. All the procedures were conducted in a glovebox with argon atmosphere. The impedance measurement from 60 to $200{ }^{\circ} \mathrm{C}$ use a Solartron. The frequency range is $1 \mathrm{MHz}^{-1} \mathrm{~Hz}$ and amplitude voltage is $100 \mathrm{mV}$. The ionic conductivity $\left(\sigma, \mathrm{S} \mathrm{cm}^{-1}\right)$ was estimated by using the equation: 


$$
\sigma=\mathrm{L} /(\mathrm{RS})
$$

where $\mathrm{L}$ is the thickness, $\mathrm{S}$ is the cross section area and $\mathrm{R}$ is the measured resistance. Activation energy was fitted by Arrhenius equation:

$$
\ln (\sigma \mathrm{T})=\ln \mathrm{A}-\frac{\mathrm{E}_{\mathrm{a}}}{k_{B} T}
$$

here, $E_{a}(\mathrm{eV})$ is the transport activation energy, $k_{B}$ is the Boltzmann constant, T $(\mathrm{K})$ is temperature, and $\mathrm{A}$ is a pre-exponential factor.

\section{$1.4 \mathrm{Li}^{+}$Transference number $\left(\mathrm{t}_{\mathrm{Li}}\right)$ measurements}

Lithium ion $\left(\mathrm{Li}^{+}\right)$transference number was tested by a constant voltage polarization method. Electrolytes were pressed into pellets. Pellet was sandwiched between two lithium metal foils to assemble into a lithium symmetric cell. Transference number measurement was carried out with CHI760E working station. A constant bias voltage of $50 \mathrm{mV}$ was imposed on electrolyte pellet. The transference number was calculated by equation of $t_{L i^{+}}=\frac{I_{S}\left[\Delta V-I_{0} R_{0}\right]}{I_{0}\left[\Delta V-I_{S} R_{S}\right]}$ where $\Delta \mathrm{V}$ is polarization voltage, $I_{0}$ and $I_{S}$ are initial current and steady-state current obtained by constant voltage polarization method testing, $R_{0}$ and $R_{S}$ are the interface resistance before and after the test.

\subsection{Electrochemical performance testing}

The electrochemical window of samples was evaluated by assembling electrolytes into coin cells, with stain steel and lithium foil as two electrodes, then tested by linear sweep voltammetry (LSV), which was measured at $100^{\circ} \mathrm{C}$ from open circuit voltage to $6 \mathrm{~V}$ using a Biological SP-200 portable working station. Cycling performance was evaluated in a $\mathrm{LiFePO}_{4}$ - Li full cell system. To boost smooth ionic conduction pathways in cathode, ionic liquids was introduced to prepare composite cathode. $\mathrm{LiFePO}_{4}$ powders, carbon black, PVDF, IL and LiTFSI were mixed in a weight ratio of 40:5:5:8:2 in NMP solution. After stirring for $12 \mathrm{~h}$, the slurry was cast on an aluminum foil and then was dried in a Compact Tape Casting Coater at $110^{\circ} \mathrm{C}$. All cells were assembled in a glovebox. To mitigate the interfacial incompatibility, PEG (Mw=10000)-LiTFSI mixture was prepared according to a molar ratio $([\mathrm{EO}] /[\mathrm{Li}]=8: 1)$ and stirred at $90{ }^{\circ} \mathrm{C}$ in a glove box until the mixtures being transparent and uniform. The $\mathrm{LiFePO}_{4}-\mathrm{Li}$ full cell was cycled between 2.5 and $4 \mathrm{~V}$ at $100^{\circ} \mathrm{C}$ in a Landt system. 


\section{Synthesis}
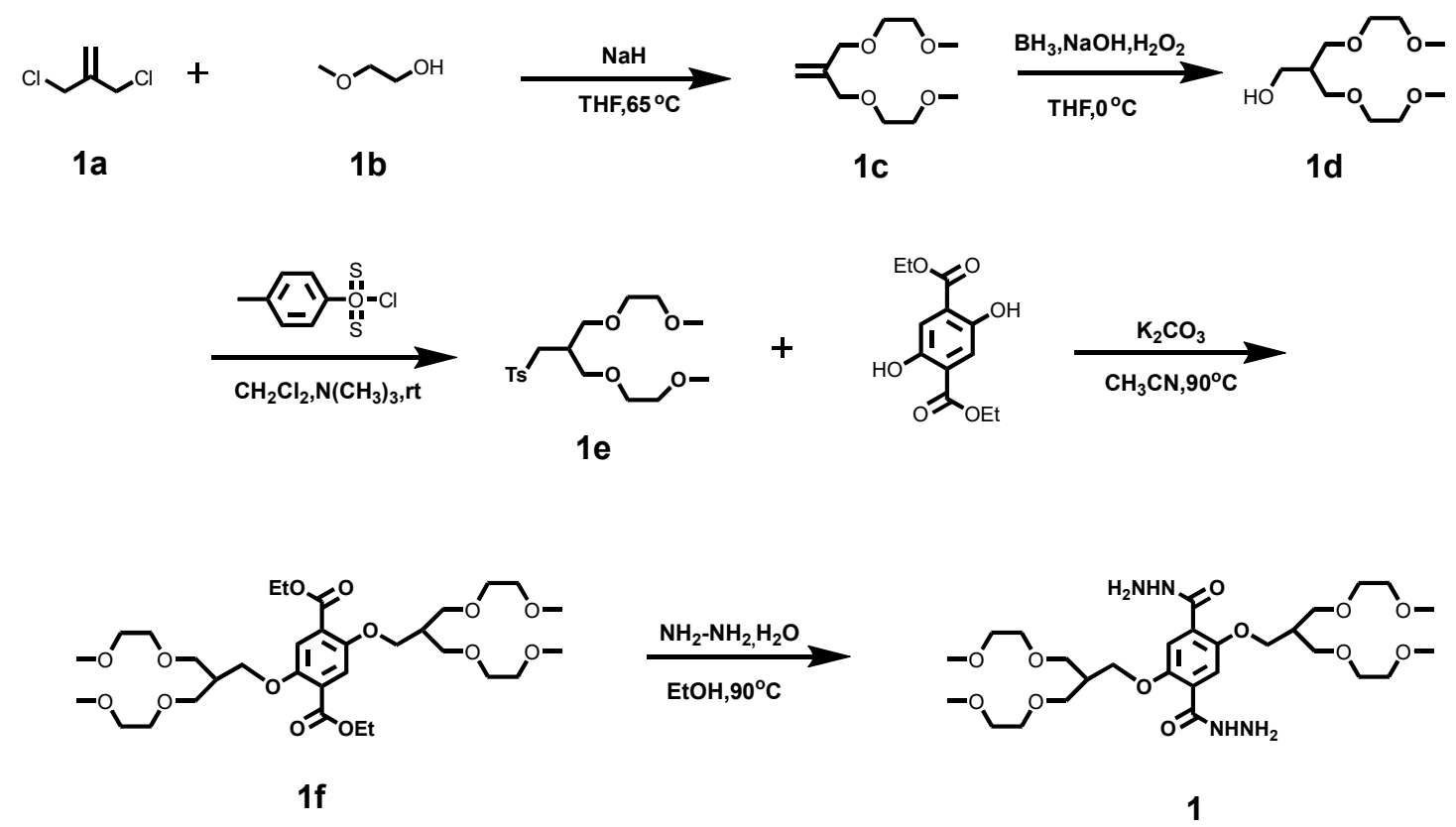

\subsection{Synthesis of $1\left(\text { PEG-B1-NHN }_{2}\right)^{\mathrm{S} 1}$}

(1c) $\mathrm{NaH}(4.97 \mathrm{~g}, 60 \%)$ add to there-necked bottle and then vacuumed and purged $\mathrm{N}_{2}$ for 3 times, then methally dichloride (5 g, $40 \mathrm{mmol})$, dry THF (70 ml) ,2methoxyethanol $(9.14 \mathrm{~g}, 120 \mathrm{mmol})$ were add to it slowly at $0{ }^{\circ} \mathrm{C}$ for 15 minutes, after this, the reaction was stirred at $65{ }^{\circ} \mathrm{C}$ for $24 \mathrm{~h}$. Upon completely, the reaction was quenched with water and extracted with dichloromethane. The organic phase was dried over anhydrous $\mathrm{MgSO}_{4}$ and concentrated under vacuum and subjected to flash column chromatography to yield a colorless liquid ( $7 \mathrm{~g}, 86 \%$ ). The product is directly put into the next step without further purification.

(1d) Dry THF (60 ml) and 1c $(6.13 \mathrm{~g}, 30 \mathrm{mmol})$ are added into a three-necked flask filled with nitrogen. Then $1 \mathrm{M} \mathrm{BH}_{3}$ solution in THF $(30 \mathrm{~mL})$ was added slowly into the flask at $0{ }^{\circ} \mathrm{C}$ and stirred for 2 hours. After completion, the reaction was quenched with a $3 \mathrm{M} \mathrm{NaOH}$ aqueous solution and stirred for an additional 15 minutes. Then the $30 \%$ $\mathrm{H}_{2} \mathrm{O}_{2}(22.81 \mathrm{ml})$ was additionally added and the mixture was stirred for another 40 minutes at the room temperature. The reaction mixture was saturated with $\mathrm{K}_{2} \mathrm{CO}_{3}$ and extracted with methylene chloride. The organic layer was dried over anhydrous $\mathrm{Na}_{2} \mathrm{SO}_{4}$ and concentrated under vacuum. Pass the obtained oil through a silica gel column yield a crude colorless liquid $(4.8 \mathrm{~g}, 72 \%)$. The product is directly put into the next step without further purification. 
(1e) $\mathrm{TsCl}$ (4.38 g, $23 \mathrm{mmol})$, Trimethylamine hydrochloride (1.91 g, $20 \mathrm{mmol})$ were add to a DCM solution of crude 1d (4.44 g, $20 \mathrm{mmol})$ under nitrogen atmosphere. Then TEA (4.05 g, $40 \mathrm{mmol}$ ) was added slowly, the reaction was stirred at room temperature for 24 hours, afterwards, the mixture was extracted through saturated sodium bicarbonate solution and dichloromethane. The organic layer was dried over anhydrous $\mathrm{Na}_{2} \mathrm{SO}_{4}$ and concentrated under vacuum. The crude product was purified by flash chromatographic column (DCM) to give a colorless liquid (4.2 g, 56\%). 1H NMR (500 $\left.\mathrm{MHz}, \mathrm{CDCl}_{3}\right) \delta(\mathrm{ppm}) 7.78(\mathrm{~d}, 2 \mathrm{H}), 7.34$ (d, 2H), $4.13(\mathrm{~d}, 2 \mathrm{H}), 3.52-3.37(\mathrm{~m}, 12 \mathrm{H}), 3.34$ $(\mathrm{s}, 6 \mathrm{H}), 2.45(\mathrm{~s}, 3 \mathrm{H}), 2.28(\mathrm{~m}, 1 \mathrm{H})$.

PEG-B1-OEt (1f): 1-bromo-2-(2-(2-methoxyethoxy)ethoxy)ethane (1.4 g, 5,5 mmol), potassium carbonate $(1.52 \mathrm{~g}, 11 \mathrm{mmol})$ were added to dry $\mathrm{MeCN}$ solution at $\mathrm{N}_{2}$ atmosphere, after the compound $1 \mathrm{e}(3.96 \mathrm{~g}, 11 \mathrm{mmol})$ added, the reaction was reflux at $90{ }^{\circ} \mathrm{C}$ for 18 hours. The resulting product was spin-dried and then extracted with dichloromethane, the organic layer was dried over anhydrous $\mathrm{Na}_{2} \mathrm{SO}_{4}$ and concentrated under vacuum, the crude product was purified by flash chromatographic column (EtOAc) to yield a colorless liquid $(1.8 \mathrm{~g}, 50 \%) .1 \mathrm{H} \mathrm{NMR}\left(500 \mathrm{MHz}, \mathrm{CDCl}_{3}\right) \delta(\mathrm{ppm})$ $7.35(\mathrm{~s}, 2 \mathrm{H}), 4.34(\mathrm{~m}, 4 \mathrm{H}), 4.09$ (d, 4H), $3.65-3.61(\mathrm{~m}, 8 \mathrm{H}), 3.60-3.56(\mathrm{~m}, 8 \mathrm{H}), 3.52-$ $3.48(\mathrm{~m}, 8 \mathrm{H}), 3.45(\mathrm{~s}, 12 \mathrm{H}), 2.35(\mathrm{~m}, 2 \mathrm{H}), 1.38(\mathrm{q}, 6 \mathrm{H}) .13 \mathrm{C} \mathrm{NMR}\left(500 \mathrm{MHz}, \mathrm{CDCl}_{3}\right)$ $\delta(\mathrm{ppm}) 165.8,151.5,124.5,116.2,71.8,70.5,69.2,67.5,61.2,59.1,39.9,14.1$.

PEG-B1-NHNH2 (1): $1.32 \mathrm{~g}$ (2 mmol) of 1f was dissolved in $15 \mathrm{ml}$ ethanol and $2 \mathrm{ml}$ hydrazine hydrate, then heated to $90{ }^{\circ} \mathrm{C}$. The mixture was stirred and heated to reflux for 18 hours, after the reaction over. The crude product was extracted with dichloromethane, organic layer was dried over anhydrous $\mathrm{Na}_{2} \mathrm{SO}_{4}$ and concentrated under vacuum. The crude product was purified by flash chromatographic column (DCM:MeOH=95:5) to yield a colorless liquid (1.1 g, 86.7\%).1H NMR (500 MHz, $\left.\mathrm{CDCl}_{3}\right) \delta(\mathrm{ppm}) 9.49(\mathrm{~s}, 2 \mathrm{H}), 7.83(\mathrm{~s}, 2 \mathrm{H}), 4.28(\mathrm{~d}, 4 \mathrm{H}), 4.25(\mathrm{~s}, 4 \mathrm{H}), 3.70-3.66(\mathrm{~m}, 4 \mathrm{H})$, 3.65-3.61 (m, 12H), 3.56-3.52 (m, 8H), $3.35(\mathrm{~s}, 12 \mathrm{H}), 2.49(\mathrm{~m}, 2 \mathrm{H}) .13 \mathrm{C}$ NMR (500 $\left.\mathrm{MHz}, \mathrm{CDCl}_{3}\right) \delta(\mathrm{ppm}) 164.6,150.8,123.3,115.5,71.9,70.8,70.4,69.7,59.0,40.0$. HRMS (EI): calcd for $\mathrm{C}_{28} \mathrm{H}_{50} \mathrm{~N}_{4} \mathrm{O}_{12} 635.35$; found 635.34991. 

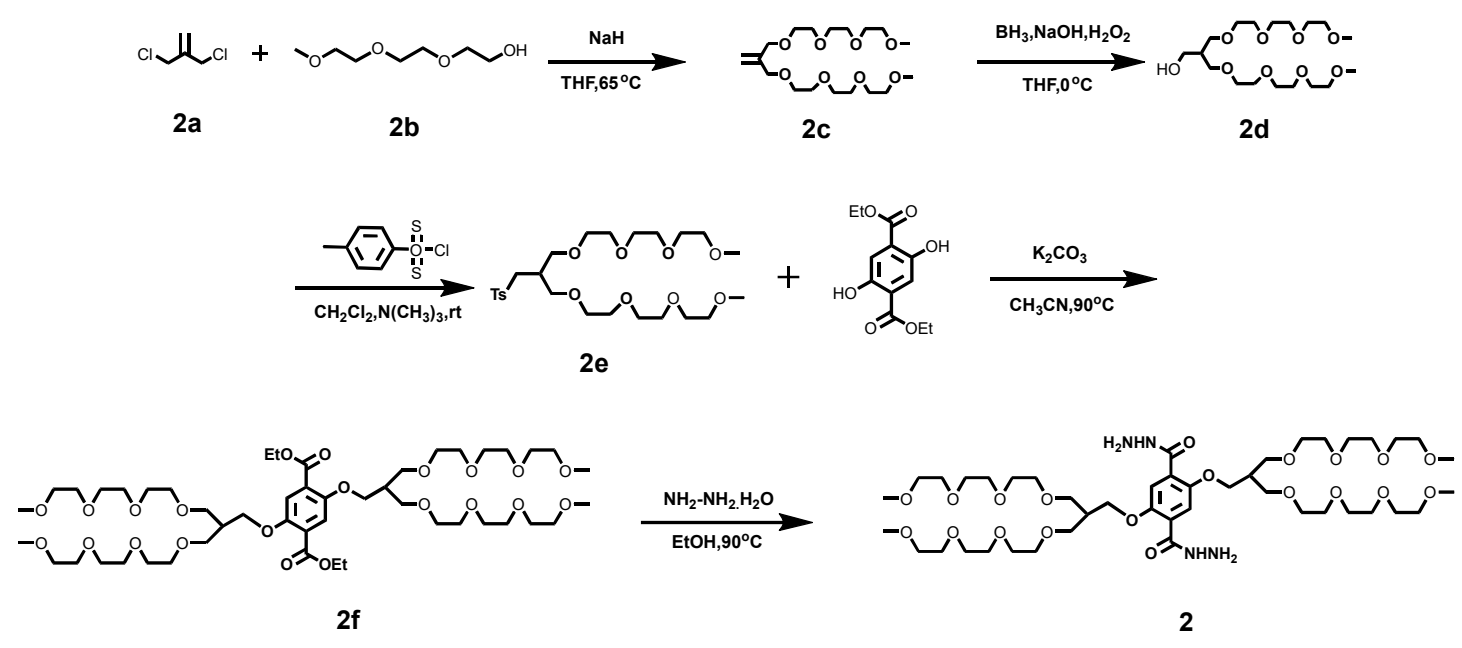

\subsection{Synthesis of 2 (PEG-B3-NHNH 2 ) 22}

(2c) $\mathrm{NaH}(4.97 \mathrm{~g}, 60 \%)$ add to three-necked bottle and then vacuumed and purged $\mathrm{N}_{2}$ for 3 times, methally dichloride (5 g, $40 \mathrm{mmol})$, dry THF (100 ml), 2-methoxyethanol $(19.7 \mathrm{~g}, 120 \mathrm{mmol})$ were add to it slowly at $0{ }^{\circ} \mathrm{C}$ for 15 minutes, after this, the reaction was stirred at $65{ }^{\circ} \mathrm{C}$ for 24 hours. Upon completely, the reaction was quenched with water and extracted with dichloromethane. The organic phase was dried over anhydrous $\mathrm{MgSO}_{4}$ and concentrated under vacuum and subjected to flash column chromatography to yield a colorless liquid (14 g, 92\%). The product is directly put into the next step without further purification.

(2d) Dry THF $(80 \mathrm{ml})$ and $2 \mathrm{c}(11.41 \mathrm{~g}, 30 \mathrm{mmol})$ are added into a three-necked flask filled with nitrogen. Then $1 \mathrm{M} \mathrm{BH}_{3}$ solution in THF $(30 \mathrm{~mL})$ was added slowly into the bottle at $0{ }^{\circ} \mathrm{C}$ and stirred for 2 hours. After completion, the reaction was quenched with a $3 \mathrm{M} \mathrm{NaOH}$ aqueous solution and stirred for an additional 15 minutes. Then the $30 \%$ $\mathrm{H}_{2} \mathrm{O}_{2}(22.81 \mathrm{ml})$ was additionally added and the mixture was stirred for another 40 minutes at room temperature. The reaction mixture was saturated with $\mathrm{K}_{2} \mathrm{CO}_{3}$ and extracted with methylene chloride. The organic layer was dried over anhydrous $\mathrm{Na}_{2} \mathrm{SO}_{4}$ and concentrated under vacuum. Pass the obtained oil through a silica gel column, yielding a crude colorless liquid (9.92 $\mathrm{g}, 83 \%)$. The product is directly put into the next step without further purification.

(2e) $\mathrm{TsCl}$ (4.38 g, 23mmol), trimethylamine hydrochloride (1.91 g, 20mmol) were add to a DCM solution of crude $2 \mathbf{d}(7.96 \mathrm{~g}, 20 \mathrm{mmol})$ under nitrogen atmosphere. Then TEA (4.05 g, 40mmol) was added slowly, the reaction was stirred at room temperature for 
24 hours, after that, the mixture was extraction through saturated sodium bicarbonate solution and dichloromethane, the organic layer was dried over anhydrous $\mathrm{Na}_{2} \mathrm{SO} 4$ and concentrated under vacuum, the crude product was purified by flash chromatographic column(DCM) to give a colorless liquid $(6.44 \mathrm{~g}, 60 \%)$. 1H NMR (500 MHz, $\left.\mathrm{CDCl}_{3}\right)$ $\delta(\mathrm{ppm}) 7.75(\mathrm{~d}, 2 \mathrm{H}), 7.34(\mathrm{~d}, 2 \mathrm{H}), 4.09-4.08$ (d, 2H), 3.62-3.44 (28m, H), 3.34 (s, 6H), $2.45(\mathrm{~s}, 3 \mathrm{H}), 2.25(\mathrm{~m}, 1 \mathrm{H})$.

PEG-B3-OEt(2f): 1-bromo-2-(2-(2-methoxyethoxy)ethoxy)-ethane (1.4 g, $5.5 \mathrm{mmol}$ ), potassium carbonate $(1.52 \mathrm{~g}, 11 \mathrm{mmol})$ were added to dry $\mathrm{MeCN}$ solution at $\mathrm{N}_{2}$ atmosphere, after the compound $2 \mathrm{e}(5.9 \mathrm{~g}, 11 \mathrm{mmol})$ adding, the reaction was refluxed at $90{ }^{\circ} \mathrm{C}$ for 24 hours. The resulting product was spin-dried and then extracted with dichloromethane. The organic layer was dried over anhydrous $\mathrm{Na}_{2} \mathrm{SO}_{4}$ and concentrated under vacuum, the crude product was purified by flash chromatographic column ( $\left.\mathrm{MeOH}: \mathrm{CH}_{2} \mathrm{Cl}_{2}=5: 95\right)$ to yield a colorless liquid $(2.3 \mathrm{~g}, 42 \%) .1 \mathrm{H}$ NMR (500 MHz, $\left.\mathrm{CDCl}_{3}\right), \delta(\mathrm{ppm}): 7.33$ (s, 2H), $4.34(\mathrm{~m}, 4 \mathrm{H}), 4.05$ (d, 2H), 3.63-3.57 (m, 48H), 3.54$3.51(\mathrm{~m}, 8 \mathrm{H}), 3.36(12 \mathrm{H}), 2.41(\mathrm{~m}, 2 \mathrm{H}), 1.36(\mathrm{q}, 6 \mathrm{H}) .13 \mathrm{C} \mathrm{NMR}\left(500 \mathrm{MHz}, \mathrm{CDCl}_{3}\right)$ $\delta(\mathrm{ppm}) 165.9,151.6,124.5,116.2,72.0,70.5,69.2,67.6,61.3,59.0,40.00,14.4$.

PEG-B3-NHNH2 (2): $2 \mathrm{~g}$ (2 mmol) of $2 \mathbf{f}$ was dissolved in $15 \mathrm{ml}$ ethanol and $2 \mathrm{ml}$ hydrazine hydrate, then heated to $90{ }^{\circ} \mathrm{C}$. The mixture was stirred and heated to reflux for 18 hours. After the reaction over, the crude product was extracted with dichloromethane, organic layer was dried over anhydrous $\mathrm{Na}_{2} \mathrm{SO}_{4}$ and concentrated under vacuum. The crude product was purified by flash chromatographic column (DCM:MeOH=95:5) to yield a colorless liquid (1.8 g, 91\%). 1H NMR (500 MHz, $\left.\mathrm{CDCl}_{3}\right) \delta(\mathrm{ppm}) 9.52(\mathrm{~s}, 2 \mathrm{H}), 7.81(\mathrm{~s}, 2 \mathrm{H}), 4.36(\mathrm{~s}, 4 \mathrm{H}), 4.24(\mathrm{~d}, 4 \mathrm{H}), 3.66-3.57(\mathrm{~m}$, $48 \mathrm{H}), 3.52-3.48(\mathrm{~m}, 8 \mathrm{H}), 3.34(\mathrm{~s}, 12 \mathrm{H}), 2.45(\mathrm{~m}, 2 \mathrm{H}) .13 \mathrm{C} \mathrm{NMR}\left(500 \mathrm{MHz}, \mathrm{CDCl}_{3}\right)$ $\delta(\mathrm{ppm}) 164.2,150.8,123.3,115.5,71.9,70.9,70.6,69.8,59.0,39.9$. HR-MS (EI): calcd for $\mathrm{C}_{44} \mathrm{H}_{82} \mathrm{~N}_{4} \mathrm{O}_{20}$ 987.56; found 987.56546 .

\subsection{Synthesis of 3 (PEG-B6-NHN 2$)^{\mathrm{S} 3}$}

(3b) $\mathrm{TsCl}$ (22.85 g, $120 \mathrm{mmol})$ were added to flask with $\mathrm{N}_{2}$, after TEA (16.7 ml, 120 mmol) and thirteen ethylene glycol monomethyl ether (52.6 ml, $360 \mathrm{mmol}), \mathrm{CH}_{2} \mathrm{Cl}_{2}$ $(150 \mathrm{ml})$ were added, the mixture was stirring at room temperature for all night. The 
reaction was extracted by sodium bicarbonate solution, after spin-drying, pass through a short silica column, yield a colorless liquid. $\left.1 \mathrm{H} \mathrm{NMR} \mathrm{(500} \mathrm{MHz,} \mathrm{CDCl}_{3}\right): \delta=7.80$ (d, 2H), 7.34 (d, 2H), 4.16-4.15 (m, 2H), 3.69-3.67 (m, 2H), 3.59-3.57 (m, 6H), 3.53-3.51 (m, 2H), 3.37 (s, 3H), $2.45(\mathrm{~s}, 3 \mathrm{H})$.

(3d) A mixture of dry triethylene glycol (18 g, $120 \mathrm{mmol})$ and $\mathrm{KOH}(1.85 \mathrm{~g}, 33.0 \mathrm{mmol})$ in THF (30 ml) was refluxed until $\mathrm{KOH}$ was dissolved. The solution was cooled to room temperature, treated with the tosylate $\mathbf{3 b}(9.55 \mathrm{~g}, 30.0 \mathrm{mmol})$, and refluxed for 18 hours. The solvent was removed under vacuum, $\mathrm{CHCl}_{3}$ was added and the organic phase was washed with water $(2 \times 50 \mathrm{~mL})$, dried over $\mathrm{Na}_{2} \mathrm{SO}_{4}$, concentrated under reduced pressure, and dried under high vacuum to give $3 \mathrm{~d}$ as a pale-yellow oil (11.57 g, $90 \%)$. The product is directly put into the next step without further purification.
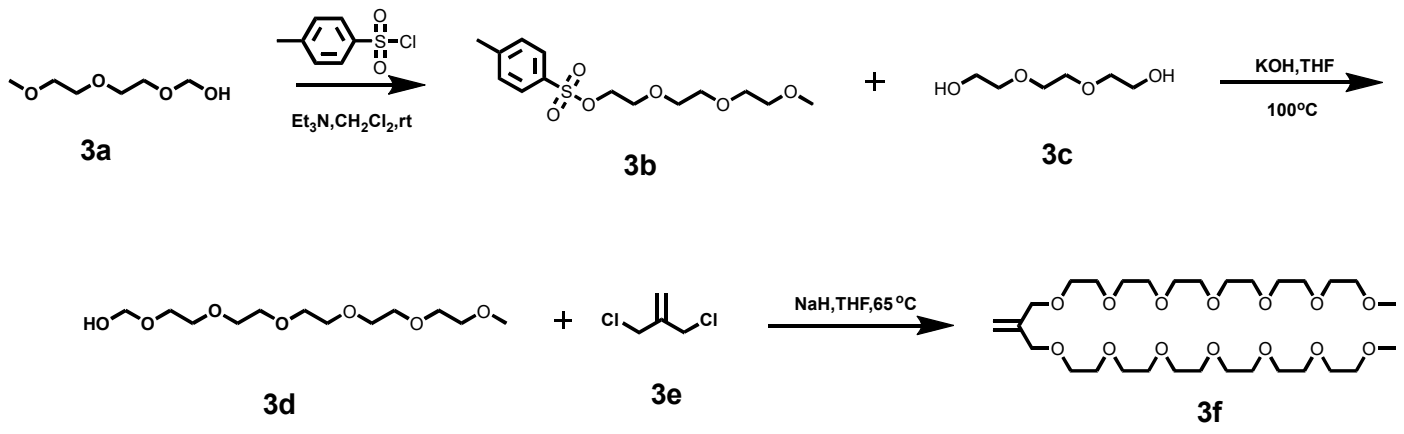

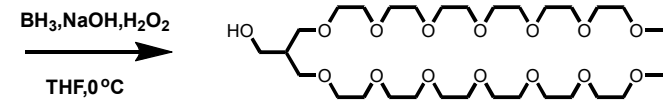

$3 g$

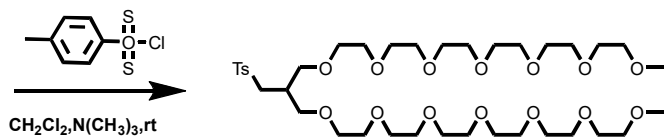

$3 h$

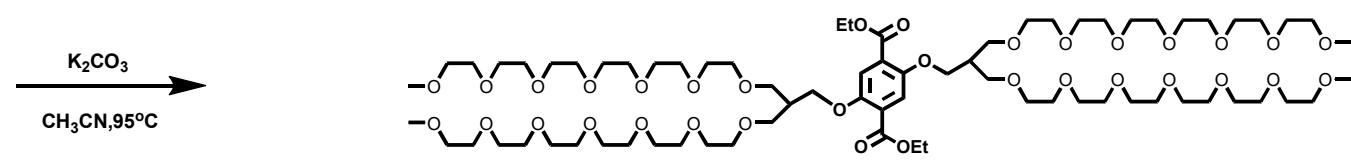

3j

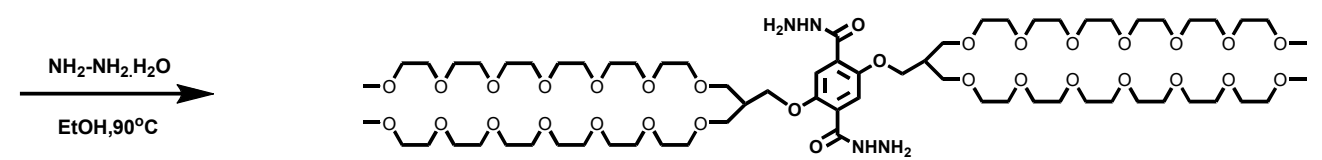

3

(3f) $\mathrm{NaH}(6.25 \mathrm{~g}, 60 \%, 50 \mathrm{mmol})$ was added to three-necked bottle and then vacuumed 
and purged $\mathrm{N}_{2}$ for 3 times, 2-methally dichloride (5 g, $\left.40 \mathrm{mmol}\right)$, dry THF (100 ml), 3d $(33.87 \mathrm{~g}, 120 \mathrm{mmol})$ were add to it slowly at $0{ }^{\circ} \mathrm{C}$ for 15 minutes. After this, the reaction was stirred at $70{ }^{\circ} \mathrm{C}$ for 24 hours. Upon completely, the reaction was quenched with water and extracted with dichloromethane. The organic phase was dried over anhydrous $\mathrm{Na}_{2} \mathrm{SO}_{4}$ and concentrated under vacuum and subjected to flash column chromatography (EtOAc) to yield a colorless liquid (20.6 g, 80\%). The product is directly put into the next step without further purification.

(3g) Dry THF (100 mL) and monomer 3f (19.34 g, $30 \mathrm{mmol})$ are added into a threenecked flask filled with nitrogen. Then $1 \mathrm{M} \mathrm{BH}_{3}$ solution in THF $(30.0 \mathrm{~mL})$ was added slowly into the bottle at $0{ }^{\circ} \mathrm{C}$ and stirred for 2 hours. After completion, the reaction was quenched with a $3 \mathrm{M} \mathrm{NaOH}$ aqueous solution and stirred for an additional 15 minutes. then the $30 \% \mathrm{H}_{2} \mathrm{O}_{2}(22.81 \mathrm{ml})$ was additionally added and the mixture was stirred for another 40 minutes at room temperature. The reaction mixture was saturated with $\mathrm{K}_{2} \mathrm{CO}_{3}$ and extracted with methylene chloride. The organic layer was dried over anhydrous $\mathrm{Na}_{2} \mathrm{SO}_{4}$ and concentrated under vacuum. Pass the obtained oil through a silica gel column (EtOAc), yielding a crude colorless liquid (16.9 g, 83\%). The product is directly put into the next step without further purification.

(3h) TsCl (4.38 g, $23 \mathrm{mmol})$, trimethylamine hydrochloride (1.91 g, $20 \mathrm{mmol}$ ) were add to a DCM solution of crude $\mathbf{3 g}$ (13.36 g, $20 \mathrm{mmol})$ under nitrogen atmosphere. Then TEA (4.05 g, $40 \mathrm{mmol}$ ) was added slowly, the reaction was stirred at room temperature for 24 hours, after that, the mixture was extracted through saturated sodium bicarbonate solution and dichloromethane. The organic layer was dried over anhydrous $\mathrm{Na}_{2} \mathrm{SO}_{4}$ and concentrated under vacuum, the crude product was purified by flash chromatographic column (DCM) to give a colorless liquid (8.8 g, 55\%). 1H NMR (500 $\mathrm{MHz}, \mathrm{CDCl}_{3}$ ) $\delta(\mathrm{ppm}) 7.76(\mathrm{~d}, 2 \mathrm{H}), 7.31(\mathrm{~d}, 2 \mathrm{H}), 4.07-4.06(\mathrm{~d}, 2 \mathrm{H}), 3.65-3.47(\mathrm{~m}, 52 \mathrm{H}), 3.34(\mathrm{~s}, 6 \mathrm{H})$, $2.43(\mathrm{~s}, 3 \mathrm{H}), 2.02(\mathrm{~m}, 1 \mathrm{H})$.

PEG-B6-OEt (3j): 1-bromo-2-(2-(2-methoxyethoxy)ethoxy)ethane (1.4 g, $5.5 \mathrm{mmol})$, potassium carbonate $(2.23 \mathrm{~g}, 16.5 \mathrm{mmol})$ were added to dry $\mathrm{MeCN}$ solution at $\mathrm{N}_{2}$ atmosphere, after the compound $\mathbf{3 h}(8.8 \mathrm{~g}, 11 \mathrm{mmol})$ added, the reaction was reflux at $95^{\circ} \mathrm{C}$ for 24 hours. The resulting product was spin-dried and then extracted with dichloromethane. The organic layer was dried over anhydrous $\mathrm{Na}_{2} \mathrm{SO}_{4}$ and concentrated 
under vacuum, the crude product was purified by flash chromatographic column (DCM:MeOH=95:5) to yield a colorless liquid (3.39 g, 40\%).1H NMR (500 MHz, $\left.\mathrm{CDCl}_{3}\right) \delta(\mathrm{ppm}) 7.34(\mathrm{~s}, 2 \mathrm{H}), 4.35(\mathrm{~m}, 4 \mathrm{H}), 4.06(\mathrm{~d}, 4 \mathrm{H}), 3.72-3.59(\mathrm{~m}, 96 \mathrm{H}), 3.56-3.52$ (m, 8H), $3.38(\mathrm{~s}, 12 \mathrm{H}), 2.43(\mathrm{~m}, 2 \mathrm{H}), 1.40(\mathrm{q}, 6 \mathrm{H}) .13 \mathrm{C} \mathrm{NMR}\left(500 \mathrm{MHz}, \mathrm{CDCl}_{3}\right) \delta(\mathrm{ppm})$ $165.8,151.6,124.5,116.2,72.0,70.6,69.3,67.6,61.2,59.0,40.0,14.4$.

PEG-B6-NHNH2 (3): $3 \mathrm{~g}(2 \mathrm{mmol})$ of $\mathbf{3 j}$ was dissolved in $15 \mathrm{ml}$ ethanol and $2 \mathrm{ml}$ hydrazine hydrate, then heated to $90{ }^{\circ} \mathrm{C}$. The mixture was stirred and heated to reflux for 24 hours, after the reaction over, the crude product was extracted with dichloromethane, organic layer was dried over anhydrous $\mathrm{Na}_{2} \mathrm{SO}_{4}$ and concentrated under vacuum. The crude product was purified by flash chromatographic column (DCM:MeOH=95:5) to yield a colorless liquid (2.7 g, 90\%).1H NMR (500 MHz, $\left.\mathrm{CDCl}_{3}\right) \delta(\mathrm{ppm}) 9.56(\mathrm{~s}, 2 \mathrm{H}), 7.85(\mathrm{~s}, 2 \mathrm{H}), 4.29(\mathrm{~d}, 4 \mathrm{H}), 3.71-3.62(\mathrm{~m}, 96 \mathrm{H}), 3.60-3.56$ $(\mathrm{m}, 8 \mathrm{H}), 3.41(\mathrm{~s}, 12 \mathrm{H}), 2.50(\mathrm{~m}, 2 \mathrm{H}) .13 \mathrm{C} \mathrm{NMR}\left(500 \mathrm{MHz}, \mathrm{CDCl}_{3}\right) \delta(\mathrm{ppm}) 164.2$, $150.7,123.4,115.5,71.95,70.86,70.58,69.8,59.0$, 39.9. HR-MS (EI): calcd for $\mathrm{C}_{66} \mathrm{H}_{130} \mathrm{~N}_{4} \mathrm{O}_{32} 1514.87$; found 1513.84619 .

\subsection{Synthesis of COF-PEG-B1}

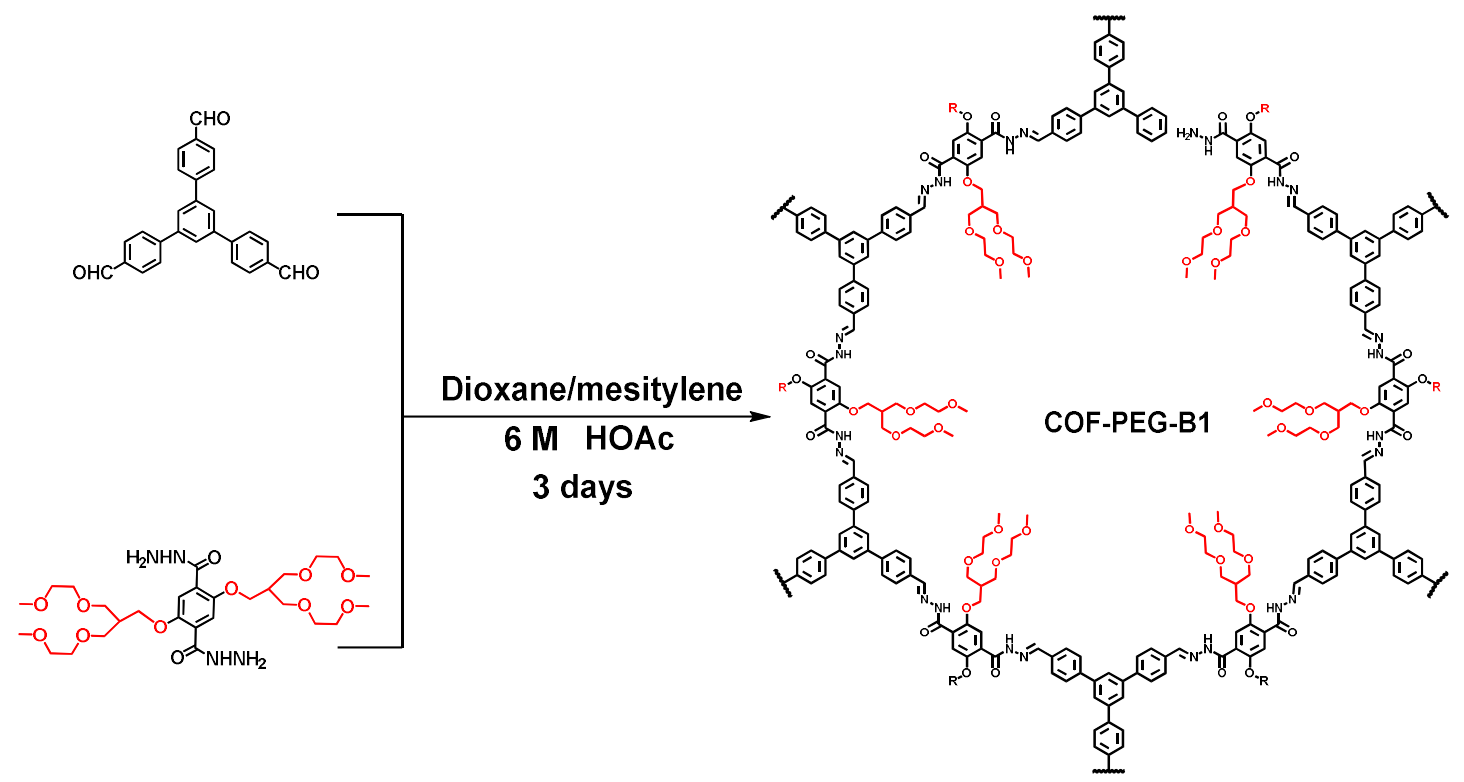

1,3,5-Trisformylbenzene 2 (39 mg, $0.10 \mathrm{mmol}$ ) and PEG-1-NHNH2 (95.2 mg, 0.15 mmol) were weighed and put into an ampoule glass bottle (volume of ca. $20 \mathrm{~mL}$, body length of $18 \mathrm{~cm}$, neck length of $9 \mathrm{~cm}$ ). After adding $2 \mathrm{ml}$ mesitylene and $6 \mathrm{~mol} \mathrm{HAc}$ $0.2 \mathrm{ml}$, the mixture was charged to ultrasound for 3 minutes, then the ampoule was flash frozen and evacuated under liquid nitrogen and to seal the tube by flame gun. Waiting 
for to stand upon to room temperature, the ampoule was heated at $120{ }^{\circ} \mathrm{C}$ for 72 hours, after reactions, the solid were taken out and washed with THF, $\mathrm{CH}_{2} \mathrm{Cl}_{2}$ and acetone, drying at $80^{\circ} \mathrm{C}$ under vacuum for 12 hours, yielding COF-PEG-B1, as a white-yellow powder.

\subsection{Synthesis of COF-PEG-B3}

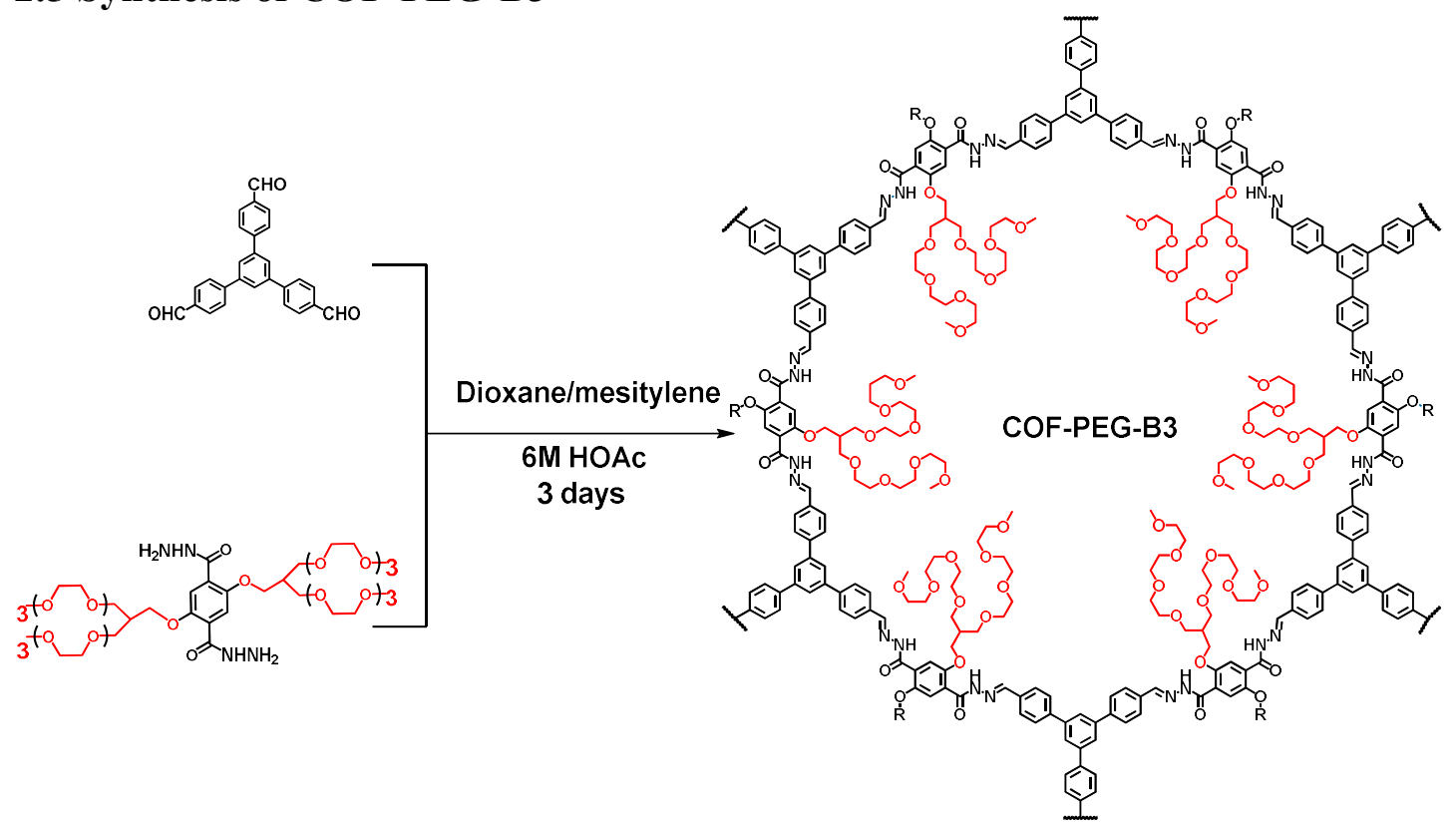

1,3,5-Trisformylbenzene 2 (39 mg, $0.10 \mathrm{mmol}$ ) and PEG-3-NHNH2 (148.1 mg, $0.15 \mathrm{mmol}$ ) were weighed and put into an ampoule glass bottle (volume of ca. $20 \mathrm{ml}$, body length of $18 \mathrm{~cm}$, neck length of $9 \mathrm{~cm}$ ). After adding $2 \mathrm{ml}$ mesitylene and $6 \mathrm{~mol}$ HAc $0.2 \mathrm{ml}$, the mixture was charged to ultrasound for 3 minutes, then the ampoule was flash frozen and evacuated under liquid nitrogen and to seal the tube by flame gun. Waiting for to stand upon to room temperature, the ampoule was heated at $120^{\circ} \mathrm{C}$ for 72 hours, after reactions, the solid were taken out and washed with THF, $\mathrm{CH}_{2} \mathrm{Cl}_{2}$ and acetone, drying at $80{ }^{\circ} \mathrm{C}$ under vacuum for 12 hours yielding COF-PEG-B3.

\subsection{Synthesis of COF-PEG-B6}




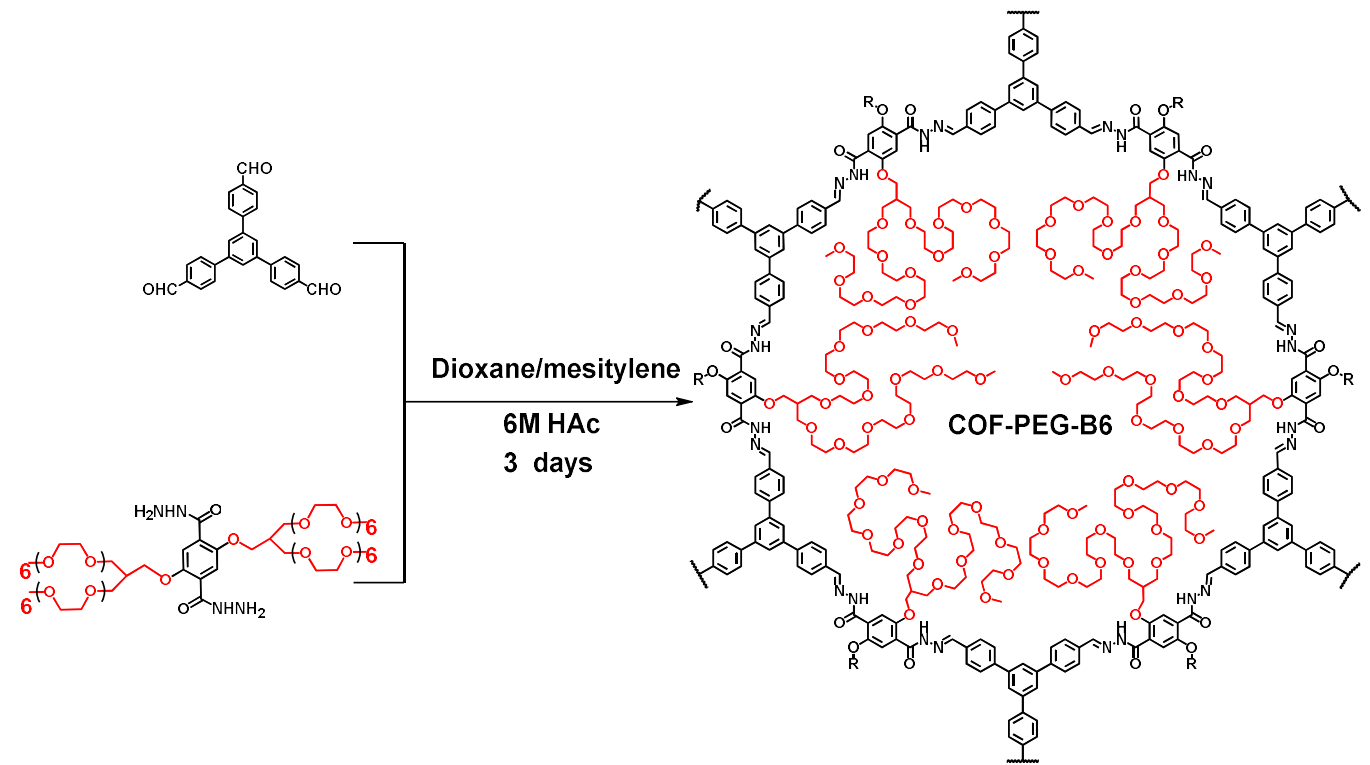

1,3,5-Trisformylbenzene 2 (39 mg, $0.10 \mathrm{mmol}$ ) and PEG6-NHNH2(227.3 mg, $0.15 \mathrm{mmol}$ ) were weighed and put into an ampoule glass bottle (volume of ca. $20 \mathrm{~mL}$, body length of $18 \mathrm{~cm}$, neck length of $9 \mathrm{~cm}$ ). After adding $2 \mathrm{ml}$ mesitylene and $6 \mathrm{~mol}$ HAc $0.2 \mathrm{ml}$, the mixture was charged to ultrasound for 3 minutes, then the ampoule was flash frozen and evacuated under liquid nitrogen and to seal the tube by flame gun. Waiting for to stand upon to room temperature, the ampoule was heated at $120{ }^{\circ} \mathrm{C}$ for 72 hours, after reactions, the solid were taken out and washed with THF, $\mathrm{CH}_{2} \mathrm{Cl}_{2}$ and acetone, drying at $80{ }^{\circ} \mathrm{C}$ under vacuum for 12 hours yielding COF-PEG-B6.

\subsection{Synthesis of COF-PEG-Bx-Li $(x=1,3,6)$}

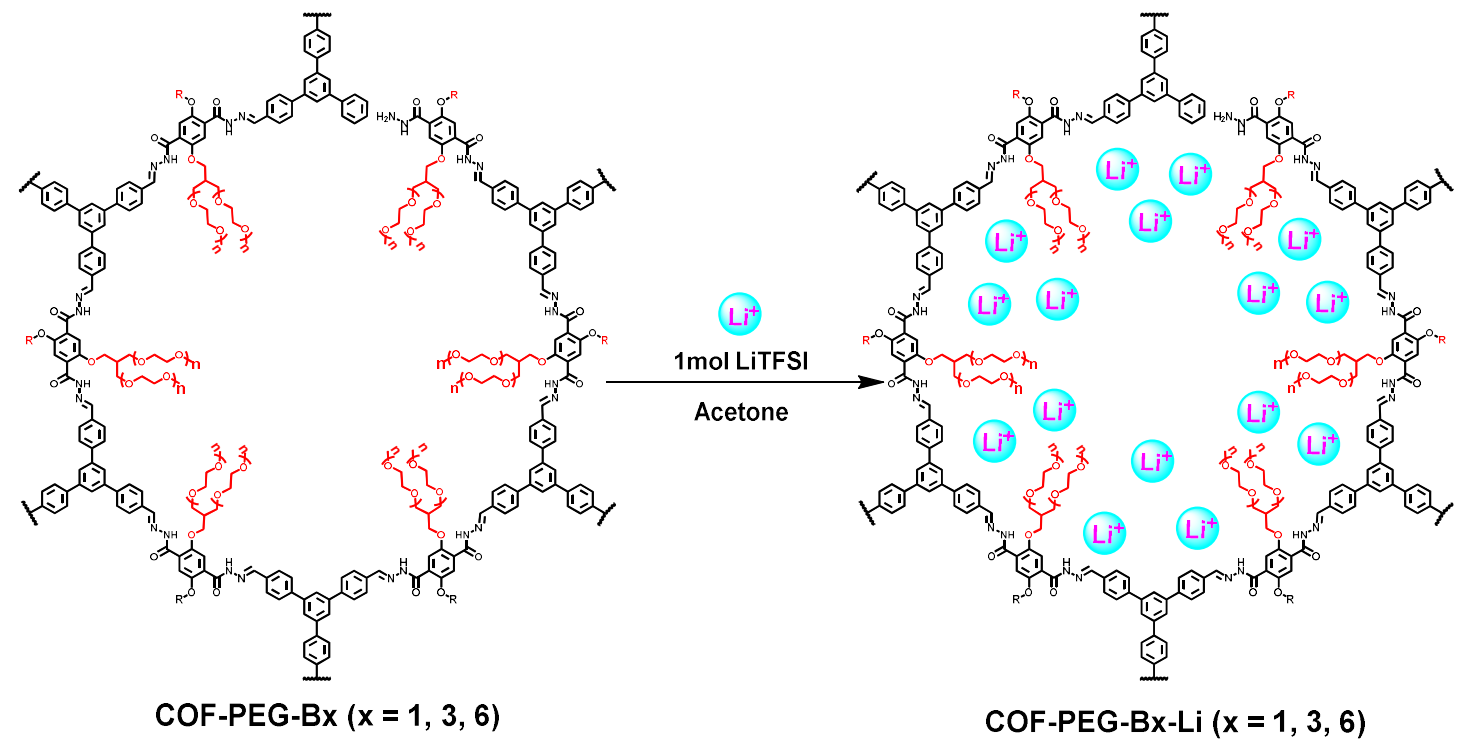

Quickly Add $2.87 \mathrm{~g}$ LITFSI to $10 \mathrm{ml}$ acetone, sonicate, then add COF-PEG-Bx $(x=1,3,6)$ powders, soak a few minutes and stand still 3 hours, suction filtration, repeat 
this operation three times, the COF-PEG-Bx $(x=1,3,6)$-Li were obtained by suction filtration into an oven at $100{ }^{\circ} \mathrm{C}$ for drying 12 hours.

\section{Characterization}

\subsection{Structural Simulation for COF-PEG-Bx $(x=1,3,6)$}

Crystal structures modeling of COF-PEG-Bx $(\mathbf{x}=\mathbf{1 , 3}, \mathbf{6})$ were generated using the Materials Studio 2019 suite of program ${ }^{3}$, The initial lattice for COF-PEG-B1 was created by starting with the space group $\mathrm{P}_{3}$, with the parameters of $\mathrm{a}=\mathrm{b}=44.94 \AA$ and $\mathrm{c}=4.48 \AA, \alpha=\beta=90^{\circ}, \gamma=120^{\circ}$, approximately predicted from the theoretical unit cell parameters in $\mathrm{P} 3$ pace group.

(a):

Powder Refinement: $\operatorname{Rwp}=5.71 \% \quad \operatorname{Rwp}(w / o$ bck $)=4.11 \% \quad R p=4.26 \%$

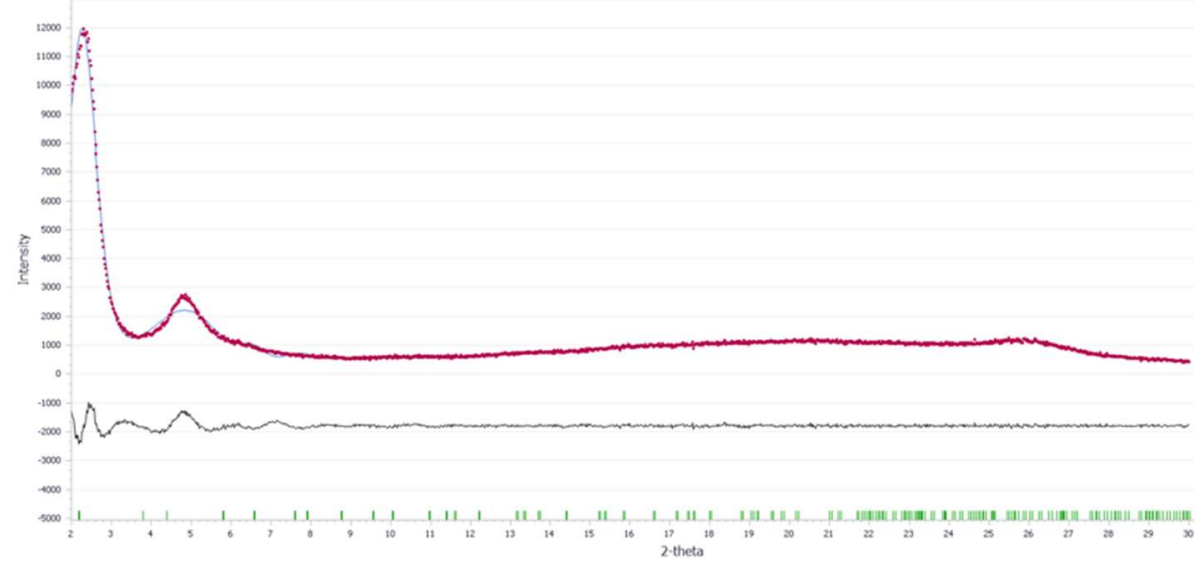


(b):

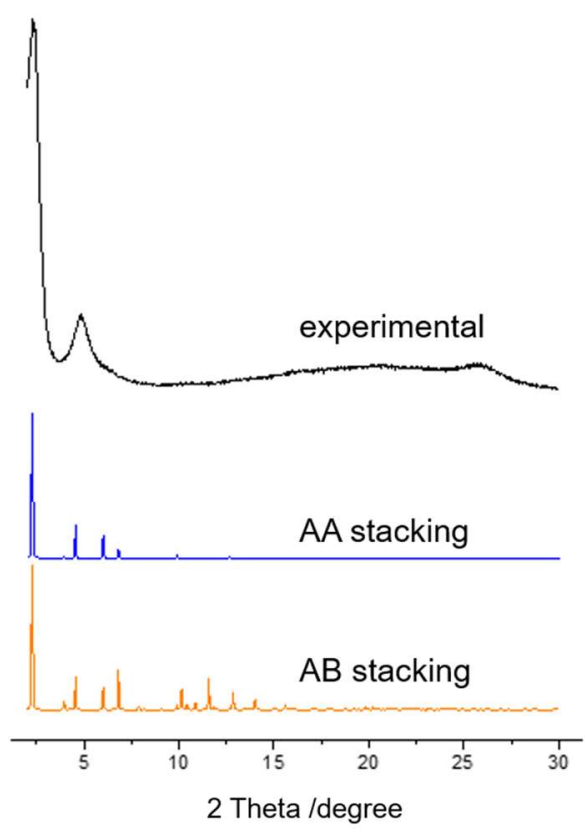

(c):

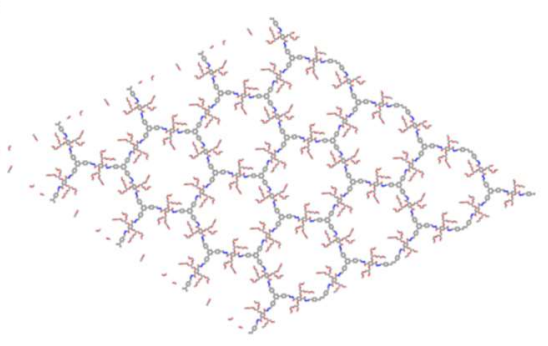

(d):

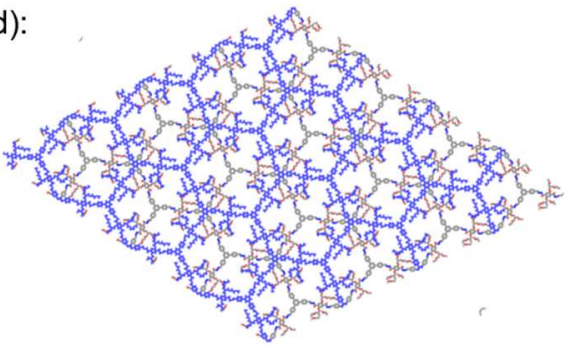

Fig. S1 (a) Pawley refinement result of COF-PEG-B1. (b) Simulated PXRD patterns for AA and AB stacking. (c) Top views of AA stacking. (d) Top views of AA stacking.

(a)

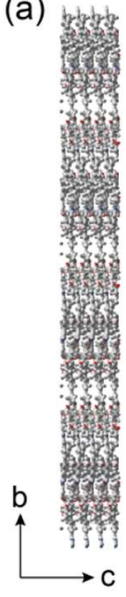

(b)

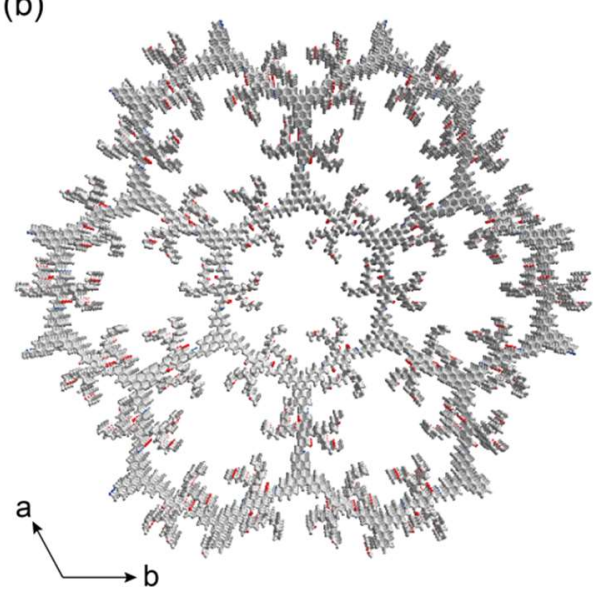

Fig. S2 (a) AAA manner along the c-axis. (b) One-dimensional channels are generated along the c-axis with PEG chain on the channel wall. 
Table S1. Fractional atomic coordinates for simulated COF-PEG-B1 powders

\begin{tabular}{|c|c|c|c|}
\hline \multicolumn{4}{|c|}{ Space group: $P 3$} \\
\hline \multicolumn{4}{|c|}{ 3D hexagonal; $\mathrm{a}=\mathrm{b}=44.94 \AA, \mathrm{c}=4.48 \AA ; \alpha=\beta=90^{\circ}, \gamma=120^{\circ}$} \\
\hline Atom & $\mathrm{X}$ & $\mathrm{Y}$ & $\mathrm{Z}$ \\
\hline $\mathrm{C} 1$ & -0.2078 & 0.15874 & -0.05622 \\
\hline $\mathrm{C} 2$ & -0.21872 & 0.12517 & 0.05824 \\
\hline $\mathrm{C} 3$ & -0.19464 & 0.11402 & 0.07958 \\
\hline $\mathrm{C} 4$ & -0.1602 & 0.13526 & -0.0086 \\
\hline $\mathrm{C} 5$ & -0.1493 & 0.16882 & -0.12344 \\
\hline C6 & -0.17338 & 0.17995 & -0.14466 \\
\hline $\mathrm{C} 7$ & -0.1365 & 0.12154 & 0.02486 \\
\hline $\mathrm{C} 8$ & -0.23144 & 0.17255 & -0.08898 \\
\hline N9 & -0.15007 & 0.086 & 0.10913 \\
\hline $\mathrm{O} 10$ & -0.26213 & 0.15433 & -0.03939 \\
\hline N11 & -0.21818 & 0.2077 & -0.17847 \\
\hline $\mathrm{O} 12$ & -0.10578 & 0.14017 & -0.01908 \\
\hline $\mathrm{C} 13$ & -0.0974 & 0.08596 & 0.1579 \\
\hline N14 & -0.13063 & 0.06966 & 0.15486 \\
\hline N15 & -0.23979 & 0.2216 & -0.20606 \\
\hline $\mathrm{C} 16$ & -0.22708 & 0.25379 & -0.27296 \\
\hline $\mathrm{C} 17$ & -0.07811 & 0.06791 & 0.1974 \\
\hline $\mathrm{C} 18$ & -0.24904 & 0.26913 & -0.30031 \\
\hline $\mathrm{C} 19$ & -0.04233 & 0.08691 & 0.20034 \\
\hline $\mathrm{C} 20$ & -0.02321 & 0.07032 & 0.2261 \\
\hline $\mathrm{C} 21$ & -0.03966 & 0.03442 & 0.24898 \\
\hline $\mathrm{C} 22$ & -0.07567 & 0.01548 & 0.24822 \\
\hline $\mathrm{C} 23$ & -0.09479 & 0.03209 & 0.22272 \\
\hline $\mathrm{C} 24$ & -0.23386 & 0.30453 & -0.34788 \\
\hline $\mathrm{C} 25$ & -0.25419 & 0.31988 & -0.36614 \\
\hline $\mathrm{C} 26$ & -0.29004 & 0.30001 & -0.33813 \\
\hline $\mathrm{C} 27$ & -0.30512 & 0.26442 & -0.29291 \\
\hline $\mathrm{C} 28$ & -0.28479 & 0.24908 & -0.27364 \\
\hline $\mathrm{C} 29$ & -0.01935 & 0.01679 & 0.26287 \\
\hline $\mathrm{C} 30$ & -0.31152 & 0.31638 & -0.34831 \\
\hline $\mathrm{C} 31$ & 0.0166 & 0.03573 & 0.26247 \\
\hline $\mathrm{C} 32$ & -0.34741 & 0.29633 & -0.34801 \\
\hline $\mathrm{O} 33$ & -0.11529 & 0.18968 & -0.23236 \\
\hline $\mathrm{C} 34$ & -0.10419 & 0.22525 & -0.26518 \\
\hline $\mathrm{C} 35$ & -0.06881 & 0.24443 & -0.4246 \\
\hline $\mathrm{C} 36$ & -0.05809 & 0.28217 & -0.44688 \\
\hline O37 & -0.02655 & 0.30046 & -0.60978 \\
\hline $\mathrm{C} 38$ & -0.02312 & 0.33244 & -0.67745 \\
\hline
\end{tabular}




\begin{tabular}{|c|c|c|c|}
\hline O39 & -0.25345 & 0.10336 & 0.13865 \\
\hline $\mathrm{C} 40$ & -0.26158 & 0.07206 & 0.30212 \\
\hline $\mathrm{C} 41$ & -0.30022 & 0.04898 & 0.31858 \\
\hline $\mathrm{C} 42$ & -0.30877 & 0.01493 & 0.47611 \\
\hline $\mathrm{O} 43$ & -0.34137 & -0.01045 & 0.37335 \\
\hline $\mathrm{C} 44$ & -0.04242 & 0.24003 & -0.22548 \\
\hline $\mathrm{O} 45$ & -0.04544 & 0.20826 & -0.29532 \\
\hline $\mathrm{C} 46$ & -0.01599 & 0.2104 & -0.15745 \\
\hline $\mathrm{C} 47$ & -0.01544 & 0.17761 & -0.22777 \\
\hline $\mathrm{O} 48$ & 0.01467 & 0.18051 & -0.09858 \\
\hline $\mathrm{C} 49$ & 0.01776 & 0.15455 & -0.25592 \\
\hline $\mathrm{C} 50$ & 0.01287 & 0.36072 & -0.5901 \\
\hline O51 & 0.03693 & 0.35725 & -0.78051 \\
\hline $\mathrm{C} 52$ & 0.06849 & 0.38471 & -0.68245 \\
\hline C53 & -0.31648 & 0.06624 & 0.51374 \\
\hline O54 & -0.35198 & 0.04824 & 0.47057 \\
\hline $\mathrm{C} 55$ & -0.36372 & 0.06629 & 0.66036 \\
\hline $\mathrm{C} 56$ & -0.40257 & 0.046 & 0.68162 \\
\hline O57 & -0.41307 & 0.01485 & 0.84387 \\
\hline C58 & -0.44875 & -0.00256 & 0.82144 \\
\hline C59 & -0.34986 & -0.03832 & 0.58345 \\
\hline $\mathrm{C} 60$ & -0.34544 & -0.06537 & 0.40029 \\
\hline O61 & -0.35685 & -0.09436 & 0.60121 \\
\hline C62 & -0.34157 & -0.11197 & 0.46512 \\
\hline $\mathrm{H} 63$ & 0.0302 & 0.06445 & 0.26181 \\
\hline $\mathrm{H} 64$ & 0.00577 & 0.14956 & -0.51368 \\
\hline H65 & 0.00443 & 0.13059 & -0.09995 \\
\hline H66 & 0.04556 & 0.16258 & -0.28092 \\
\hline $\mathrm{H} 67$ & 0.01778 & 0.35923 & -0.31403 \\
\hline $\mathrm{H} 68$ & 0.01535 & 0.38626 & -0.64584 \\
\hline H69 & 0.08178 & 0.40101 & -0.90883 \\
\hline $\mathrm{H} 70$ & 0.08471 & 0.37475 & -0.57109 \\
\hline H71 & 0.06437 & 0.40047 & -0.48856 \\
\hline $\mathrm{H} 72$ & 0.79716 & 0.08741 & 0.16937 \\
\hline $\mathrm{H} 73$ & 0.8348 & 0.20656 & -0.23467 \\
\hline $\mathrm{H} 74$ & 0.82237 & 0.06928 & 0.143 \\
\hline $\mathrm{H} 75$ & 0.80919 & 0.22416 & -0.22653 \\
\hline $\mathrm{H} 76$ & 0.91726 & 0.11455 & 0.12989 \\
\hline $\mathrm{H} 77$ & 0.80123 & 0.27056 & -0.31131 \\
\hline $\mathrm{H} 78$ & 0.97105 & 0.11556 & 0.18195 \\
\hline $\mathrm{H} 79$ & 1.0055 & 0.08568 & 0.22863 \\
\hline $\mathrm{H} 80$ & 0.9107 & -0.01317 & 0.26817 \\
\hline H81 & 0.8765 & 0.01676 & 0.22249 \\
\hline
\end{tabular}




\begin{tabular}{|c|c|c|c|}
\hline H82 & 0.7947 & 0.32061 & -0.37141 \\
\hline H83 & 0.75807 & 0.34827 & -0.40343 \\
\hline H84 & 0.66632 & 0.24808 & -0.27197 \\
\hline H85 & 0.70293 & 0.22068 & -0.23678 \\
\hline H86 & 0.63994 & 0.26766 & -0.34752 \\
\hline H87 & 0.89665 & 0.23624 & -0.00831 \\
\hline $\mathrm{H} 88$ & 0.87734 & 0.2285 & -0.42954 \\
\hline H89 & 0.92968 & 0.23437 & -0.68748 \\
\hline $\mathrm{H} 90$ & 0.94399 & 0.29266 & -0.18504 \\
\hline H91 & 0.92219 & 0.28508 & -0.59335 \\
\hline H92 & 0.95786 & 0.33567 & -0.52202 \\
\hline $\mathrm{H} 93$ & 0.97194 & 0.33415 & -0.95303 \\
\hline H94 & 0.74918 & 0.07757 & 0.56535 \\
\hline H95 & 0.74982 & 0.05885 & 0.15597 \\
\hline H96 & 0.68947 & 0.04413 & 0.05361 \\
\hline H97 & 0.69182 & 0.01726 & 0.759 \\
\hline H98 & 0.71059 & 0.00771 & 0.3934 \\
\hline H99 & 0.95352 & 0.2418 & 0.05218 \\
\hline $\mathrm{H} 100$ & 0.98398 & 0.26079 & -0.29714 \\
\hline H101 & 0.9843 & 0.21437 & 0.12305 \\
\hline H102 & 1.00721 & 0.23254 & -0.27398 \\
\hline $\mathrm{H} 103$ & 0.98342 & 0.17316 & -0.50796 \\
\hline $\mathrm{H} 104$ & 0.96191 & 0.15553 & -0.10339 \\
\hline H105 & 0.69409 & 0.09312 & 0.41907 \\
\hline H106 & 0.68956 & 0.06685 & 0.78994 \\
\hline H107 & 0.64453 & 0.09165 & 0.53685 \\
\hline H108 & 0.6473 & 0.07059 & 0.92219 \\
\hline H109 & 0.58639 & 0.04109 & 0.41965 \\
\hline H110 & 0.58808 & 0.06102 & 0.82834 \\
\hline H111 & 0.54088 & 0.96971 & 0.8842 \\
\hline H112 & 0.54345 & 0.99975 & 0.55751 \\
\hline H113 & 0.54074 & 1.00889 & 1.00458 \\
\hline H114 & 0.6228 & 0.95034 & 0.66646 \\
\hline H115 & 0.66722 & 0.97039 & 0.81178 \\
\hline H116 & 0.68235 & 0.94516 & 0.33924 \\
\hline H117 & 0.63936 & 0.92737 & 0.15937 \\
\hline H118 & 0.65365 & 0.8849 & 0.1853 \\
\hline H119 & 0.64722 & 0.86214 & 0.58678 \\
\hline H120 & 0.68673 & 0.90286 & 0.51372 \\
\hline
\end{tabular}


Table S2. Summary of the MOFs/COFs based electrolytes for lithium ion conduction.

\begin{tabular}{|c|c|c|c|c|c|}
\hline Materials & $\sigma\left(\mathrm{S} \mathrm{cm}^{-1}\right)$ & $\mathrm{Ea}(\mathrm{eV})$ & Condition & Description & Ref. \\
\hline COF-PEG-B6-Li & $1.5 \times 10^{-3}$ & 0.6 & $200{ }^{\circ} \mathrm{C}$ & $\begin{array}{l}\text { PEG grafted on } \\
\text { framework }\end{array}$ & This work \\
\hline Li-IL@MOF(MOF-525(Cu)) & $4.9 \times 10^{-3}$ & & $100^{\circ} \mathrm{C}$ & MOF & $\begin{array}{l}\text { Adv. Mater. 2018, 30, } \\
1704436\end{array}$ \\
\hline COF-PEO-9 & $1.33 \times 10^{-3}$ & & $200^{\circ} \mathrm{C}$ & $\begin{array}{l}\text { PEG grafted on } \\
\text { framework }\end{array}$ & $\begin{array}{l}\text { J. Am. Chem. Soc. } 2019 \text {, } \\
141,3,1227-1234\end{array}$ \\
\hline PEG-Li+@EB-COF-ClO 4 & $1.78 \times 10^{-3}$ & 0.17 & $120^{\circ} \mathrm{C}$ & $\begin{array}{l}\text { PEG comfined in COF } \\
\text { channels }\end{array}$ & $\begin{array}{l}\text { J. Am. Chem. Soc. } 2019 \text {, } \\
\text { 141, 1923-1927. }\end{array}$ \\
\hline TPB-BMTP-COF & $5.49 \times 10^{-4}$ & 0.30 & $90^{\circ} \mathrm{C}$ & $\begin{array}{l}\text { Covalently anchoring } \\
\text { flexible chains }\end{array}$ & $\begin{array}{l}\text { J. Am. Chem. Soc. } 2018 \text {, } \\
\text { 140, 7429-7432. }\end{array}$ \\
\hline COF-5(Mechanically Shaped) & $2.6 \times 10^{-4}$ & 0.037 & RT & $\mathrm{COF}+\mathrm{THF}$ & $\begin{array}{l}\text { J. Am. Chem. Soc. 2016, } \\
138,9767-9770 .\end{array}$ \\
\hline UiO-66-LiSS & $7.8 \times 10-4$ & 0.21 & $\mathrm{RT}$ & MOF & $\begin{array}{l}\text { ACS Appl. Energy Mater. } \\
2020,3,4007-4013\end{array}$ \\
\hline $\mathrm{TpPa}-\mathrm{SO}_{3} \mathrm{Li}$ & $2.7 \times 10^{-5}$ & 0.18 & RT & $\mathrm{COF}+$ Solvent-Free & $\begin{array}{l}\text { J. Am. Chem. Soc. } 2019 \text {, } \\
\text { 141, 14, 5880-5885. }\end{array}$ \\
\hline $\begin{array}{l}\text { ICOF with Spiroborate } \\
\text { Linkage }\end{array}$ & $3.05 \times 10^{-5}$ & 0.24 & RT & $\mathrm{COF}+\mathrm{PC}$ & $\begin{array}{l}\text { Angew. Chem. Int. Ed. } \\
\text { 2016, 55, 1737-1741. }\end{array}$ \\
\hline
\end{tabular}


3.2 XRD, Nitrogen adsorption, TGA, IF-TR, DSC and ssNMR

(a)

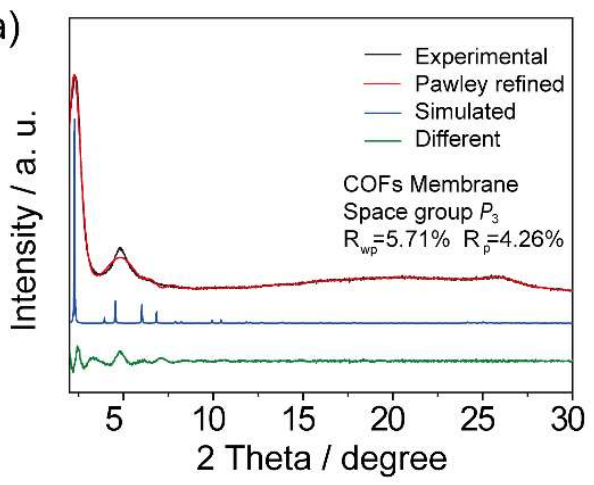

(c)

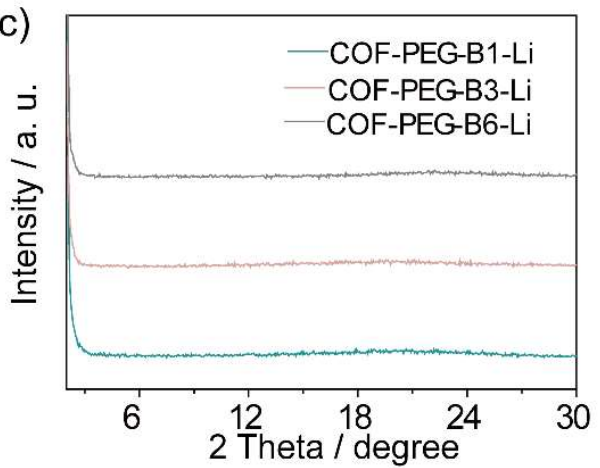

(b)

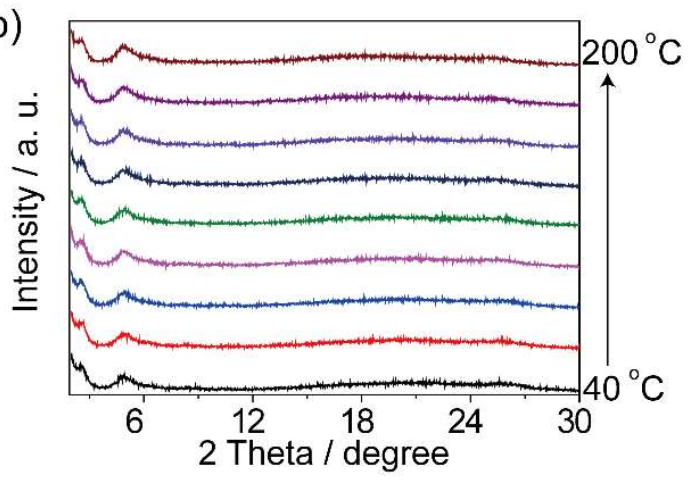

(d)

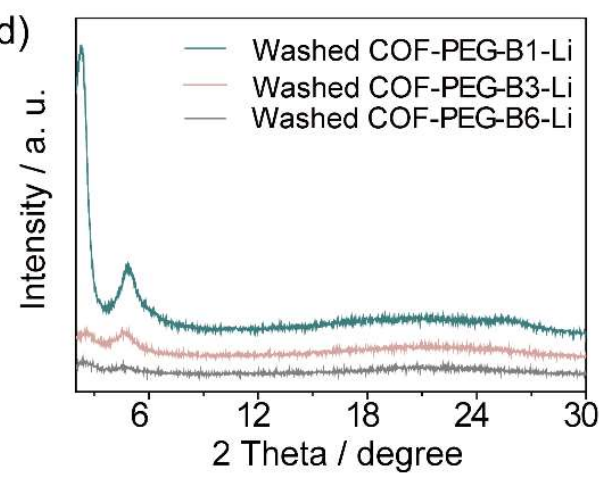

Fig. S3 PXRD patterns with the experimental profiles (a) for COF-PEG-B1. (b) Temperature dependent PXRD of COF-PEG-B1 from $40{ }^{\circ} \mathrm{C}$ to $200{ }^{\circ} \mathrm{C}$. The temperature interval is $20^{\circ} \mathrm{C}$. (c) PXRD of COF-PEG-B1-Li, COF-PEG-B3-Li and COF-PEG-B6-Li. (d) PXRD pattern of water washed COF-PEG-B1-Li, COF-PEGB3-Li and COF-PEG-B6-Li.

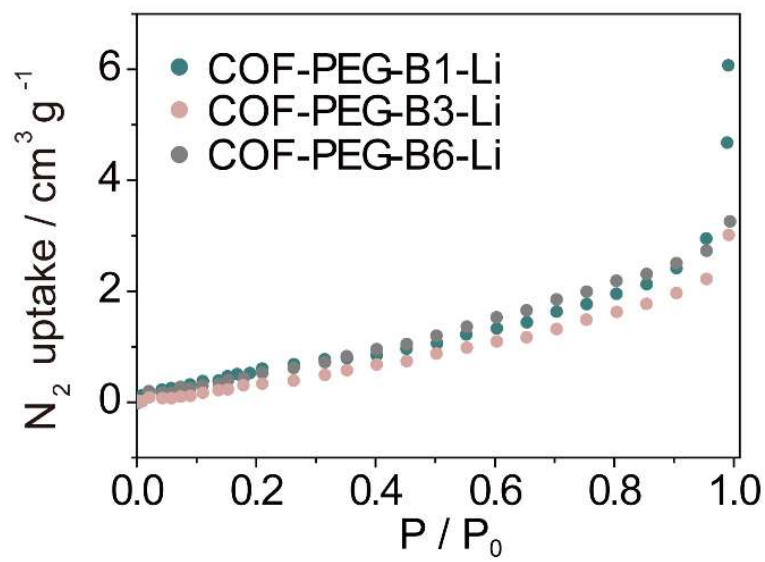

Fig. S4 $\mathrm{N}_{2}$ adsorption of COF-PEG-B1-Li, COF-PEG-B3-Li and COF-PEG-B6-Li. 


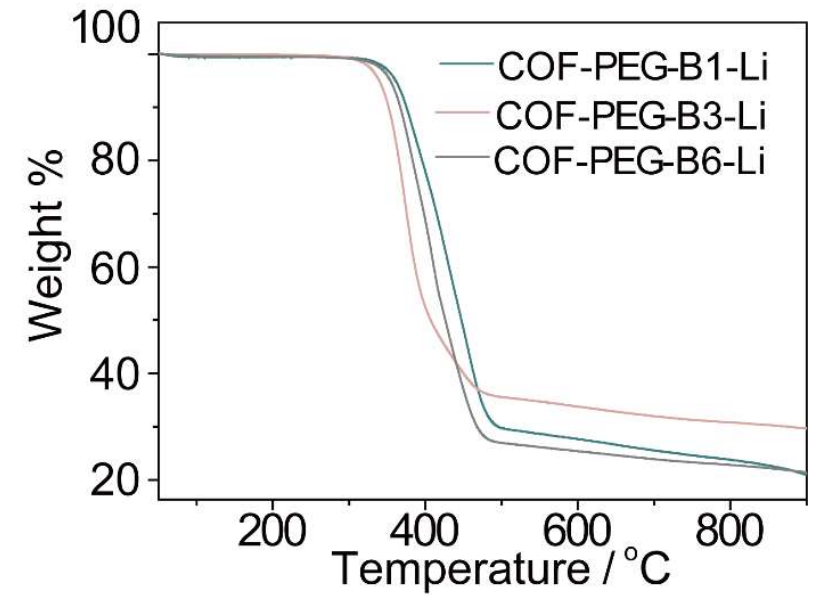

Fig. S5 TG profiles of COF-PEG-B1-Li, COF-PEG-B3-Li and COF-PEG-B6-Li.

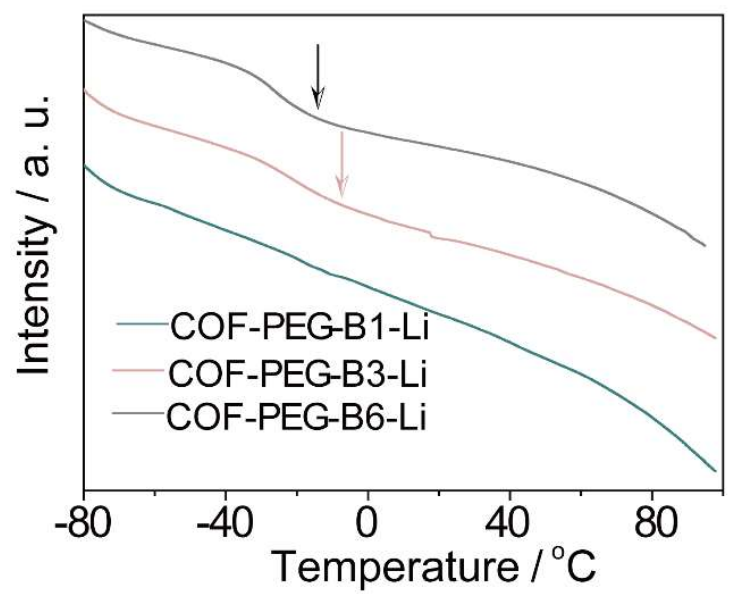

Fig. S6 DSC profiles of COF-PEG-B1-Li, COF-PEG-B3-Li and COF-PEG-B6-Li.

(a)

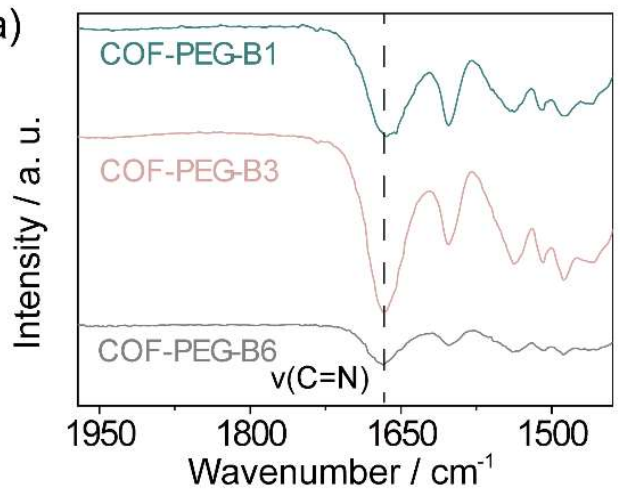

(b)

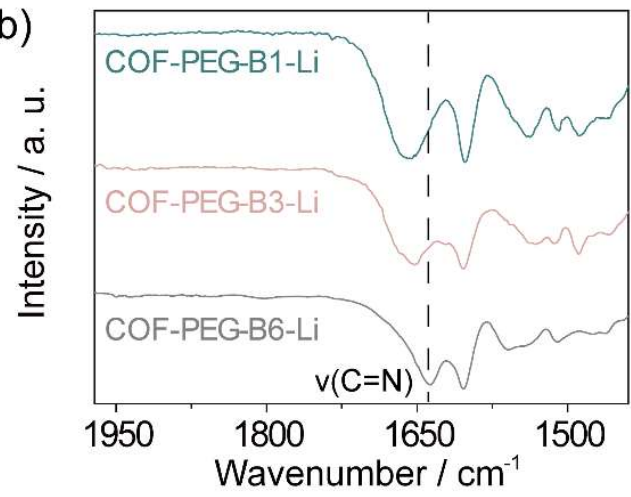

Fig. 57 (a) IR plot of COF-PEG-B1, COF-PEG-B3 and COF-PEG-B6. (b) IR profiles of COF-PEG-B1-Li, COF-PEG-B3-Li and COF-PEG-B6-Li. 


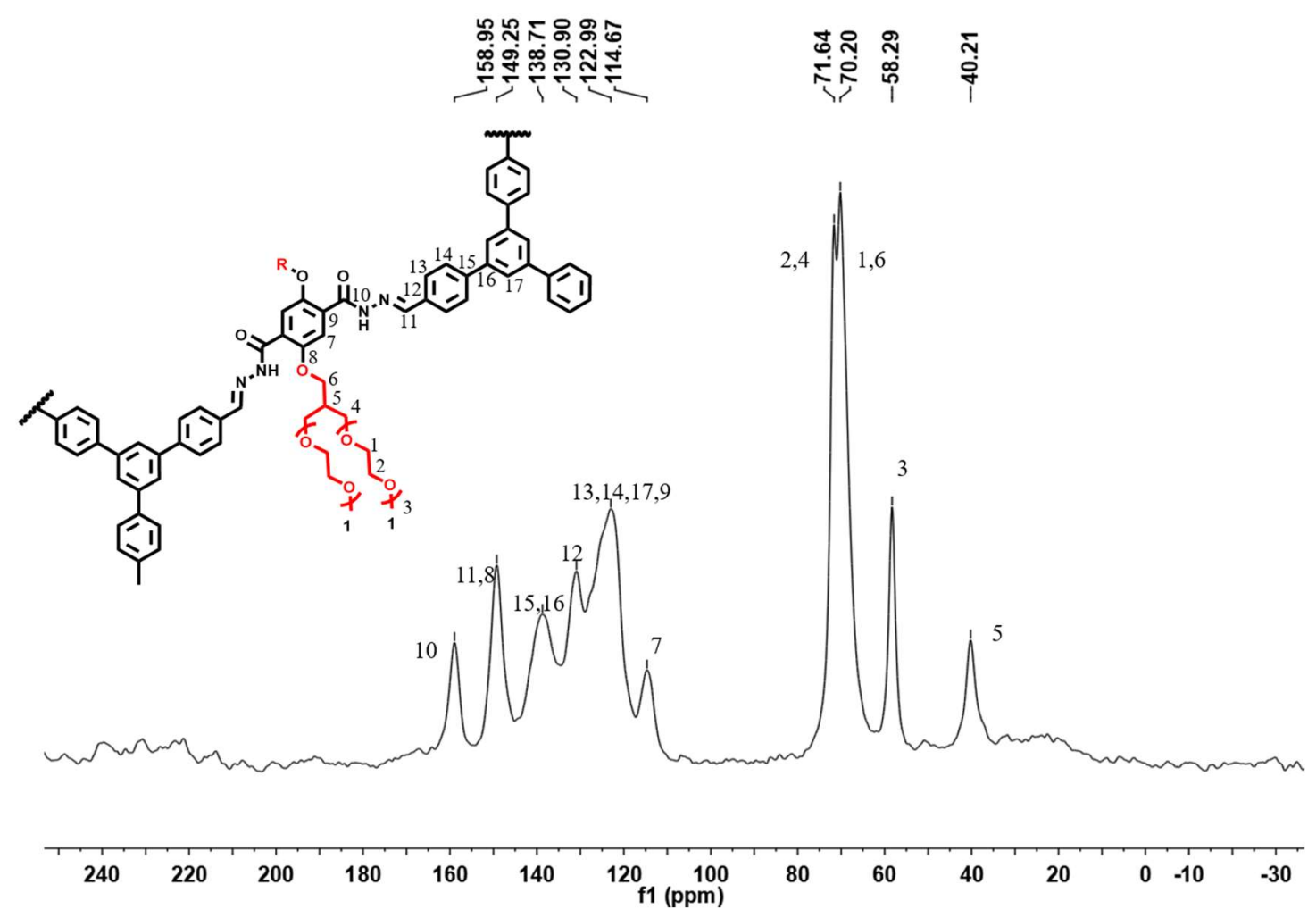

Fig. S8 ${ }^{13} \mathrm{C}$ NMR spectra date of COF-PEG-B1.

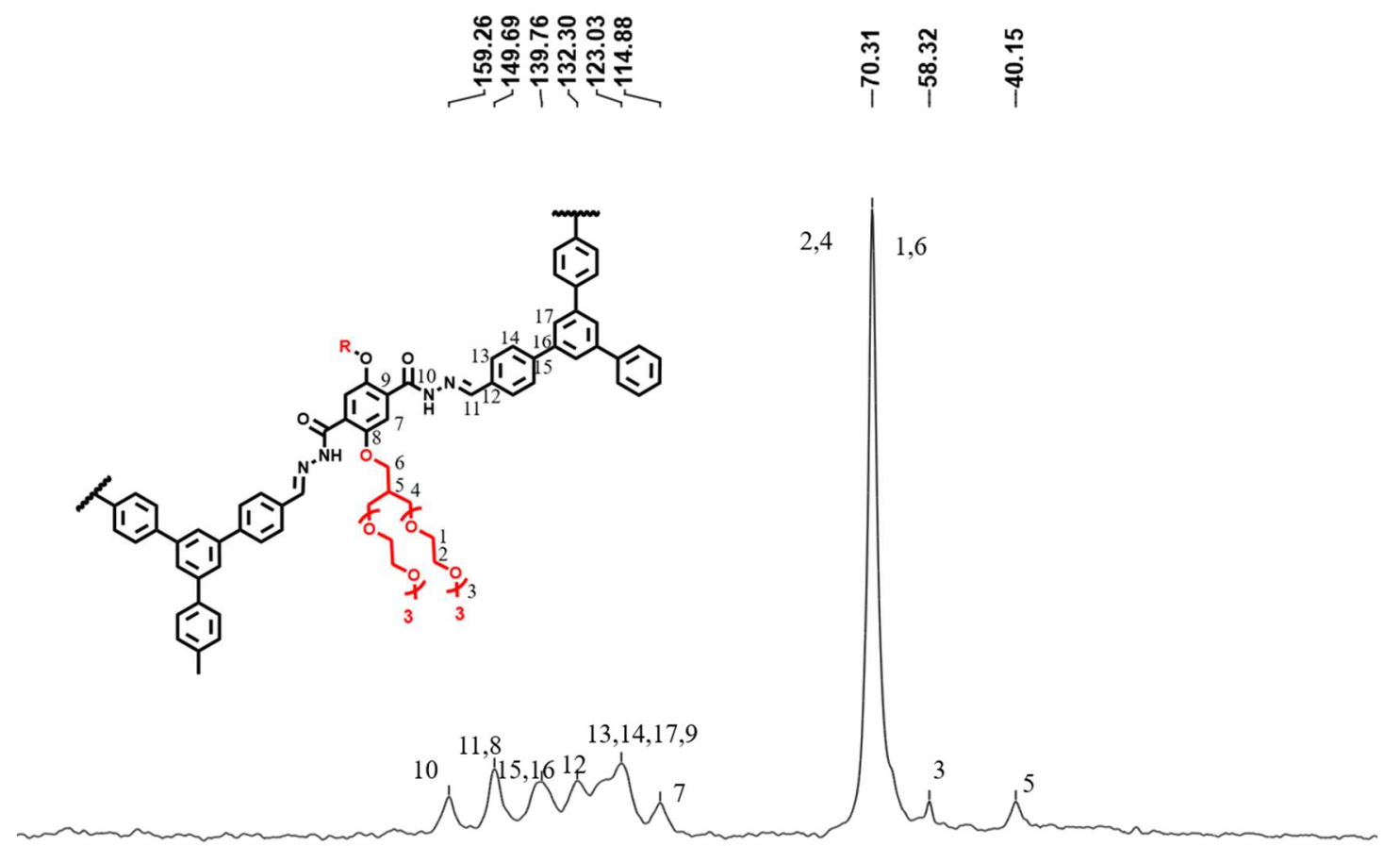

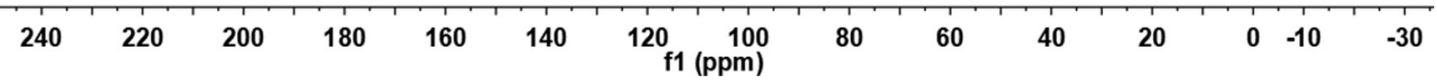

Fig. S9 ${ }^{13} \mathrm{C}$ NMR spectra date of COF-PEG-B3. 


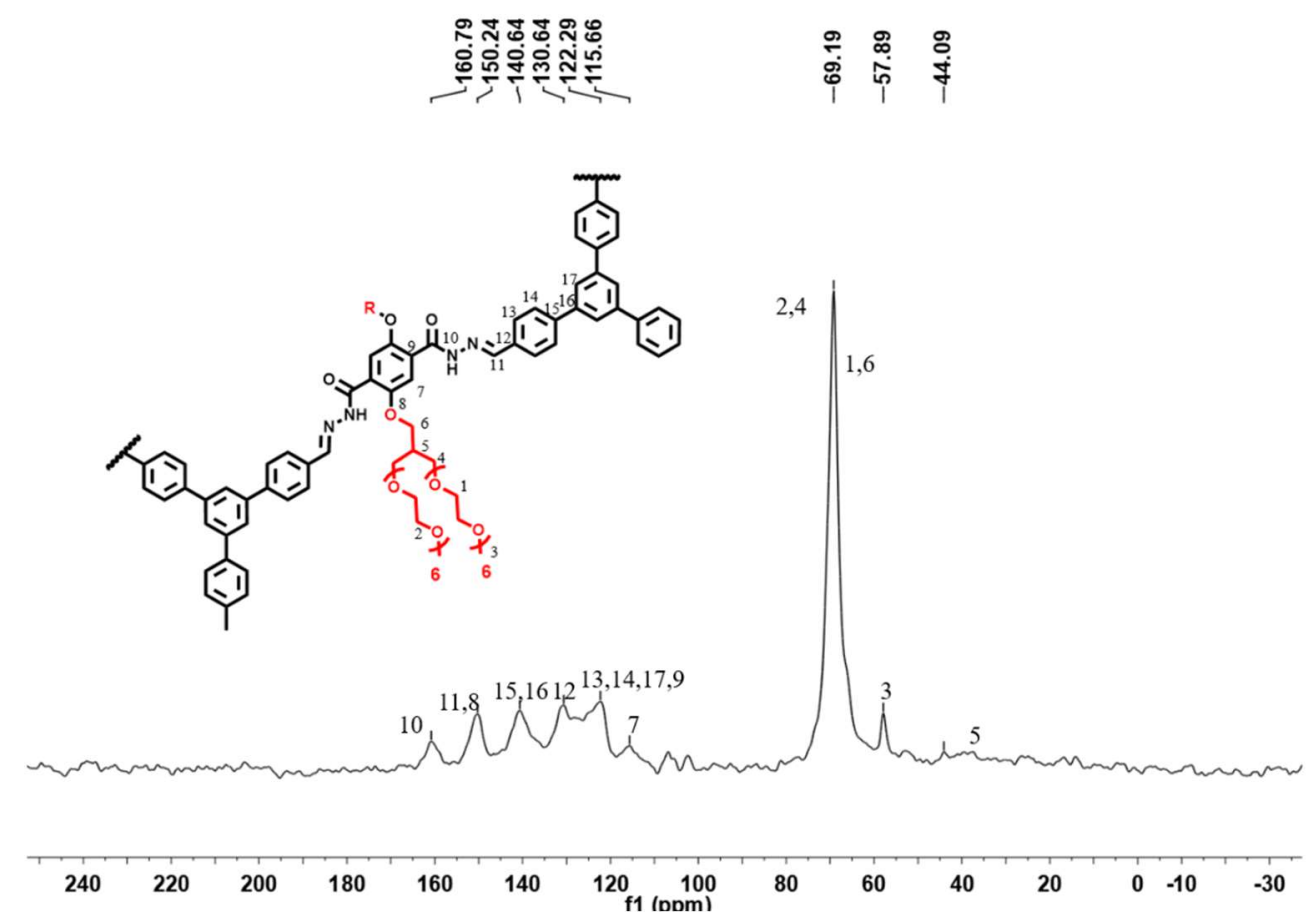

Fig. S10 ${ }^{13} \mathrm{C}$ NMR spectra date of COF-PEG-B6.

\subsection{Ionic conductivity of COFs}

(a)

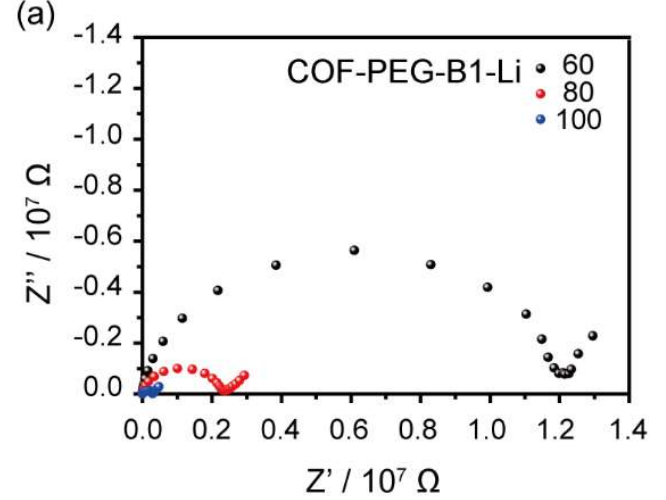

(b)

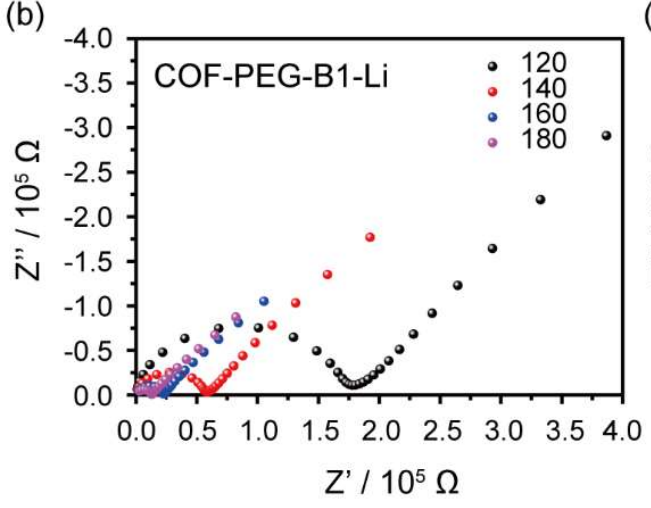

(c)

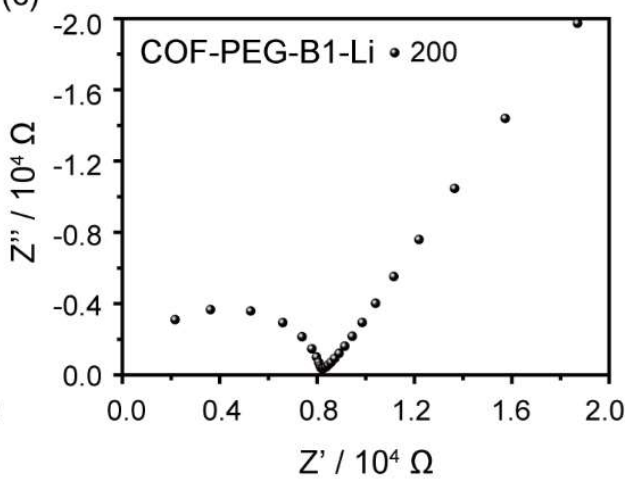

Fig. S11 Nyquist plots of COF-PEG-B1-Li (a) from $60{ }^{\circ} \mathrm{C}$ to $100{ }^{\circ} \mathrm{C}$, (b) from $120{ }^{\circ} \mathrm{C}$ to $200{ }^{\circ} \mathrm{C}$ and (c) at $200{ }^{\circ} \mathrm{C}$. 
(a)

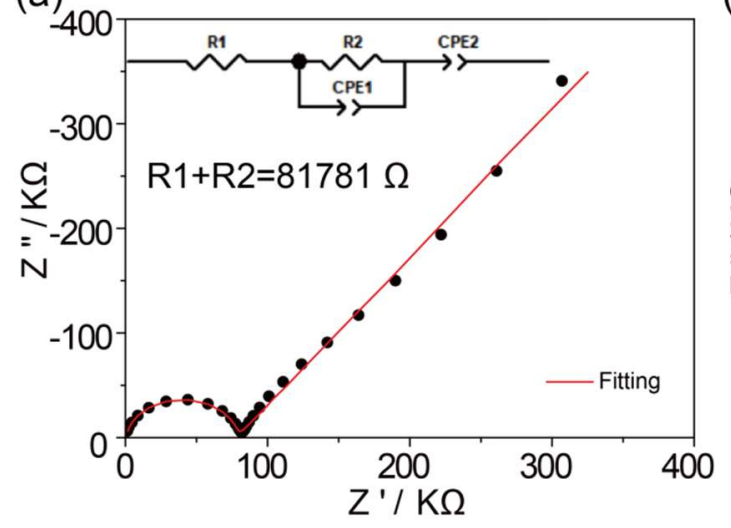

(b)

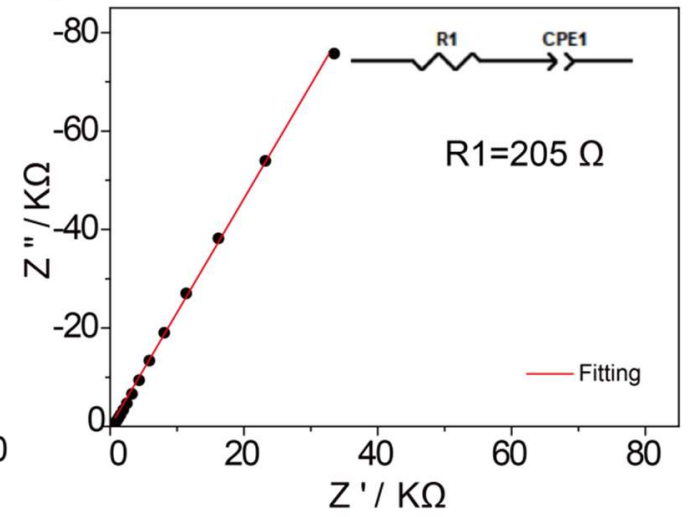

Fig. S12 Examples of impedance fitting results. (a) Nyquist plot of COF-PEG-B6-Li at $60{ }^{\circ} \mathrm{C}$. (b) Nyquist plot of COF-PEG-B6-Li at $200^{\circ} \mathrm{C}$.
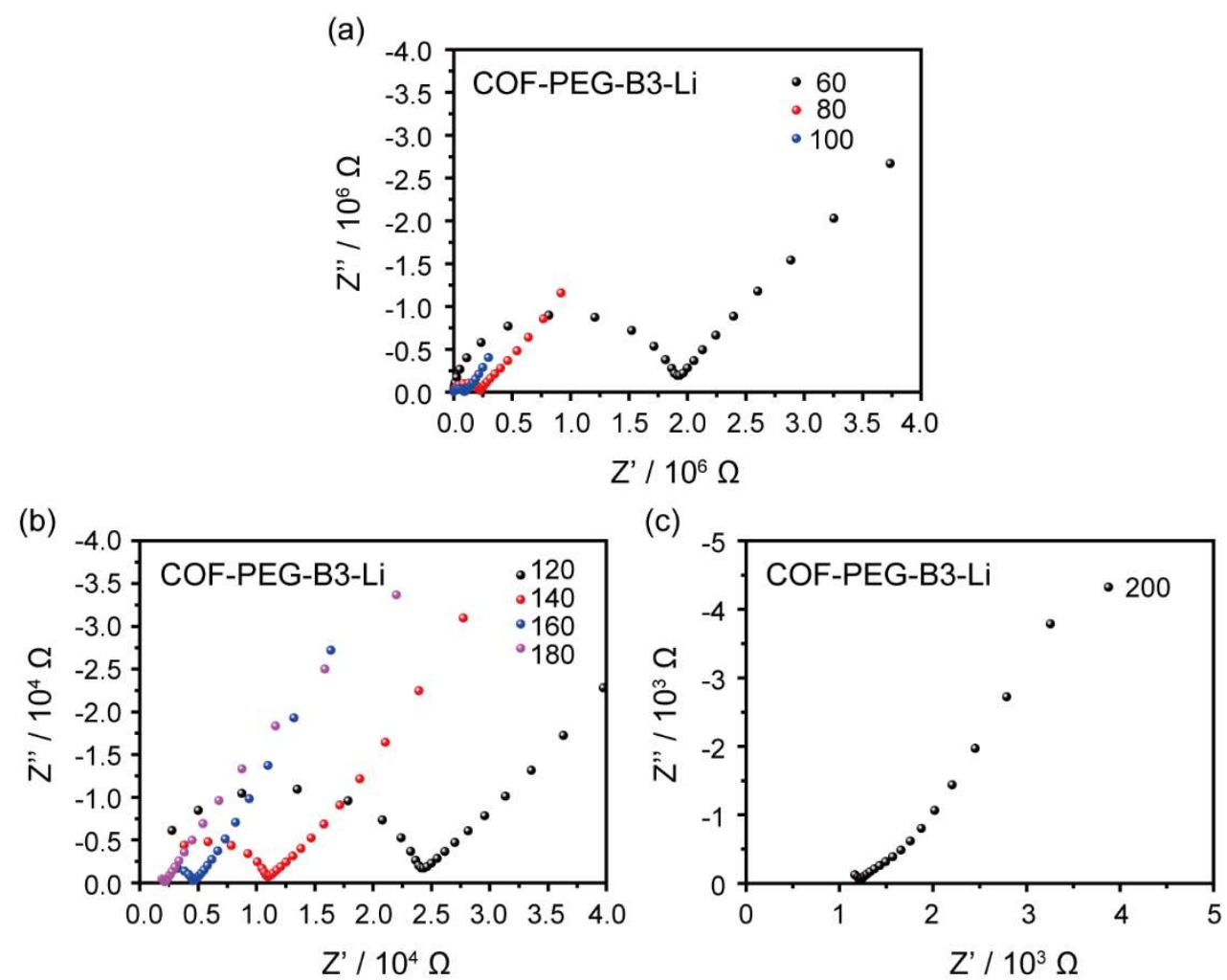

Fig. S13 Nyquist plots of COF-PEG-B3-Li (a) from $60{ }^{\circ} \mathrm{C}$ to $100{ }^{\circ} \mathrm{C}$, (b) from $120^{\circ} \mathrm{C}$ to $200{ }^{\circ} \mathrm{C}$ and (c) at $200{ }^{\circ} \mathrm{C}$. 

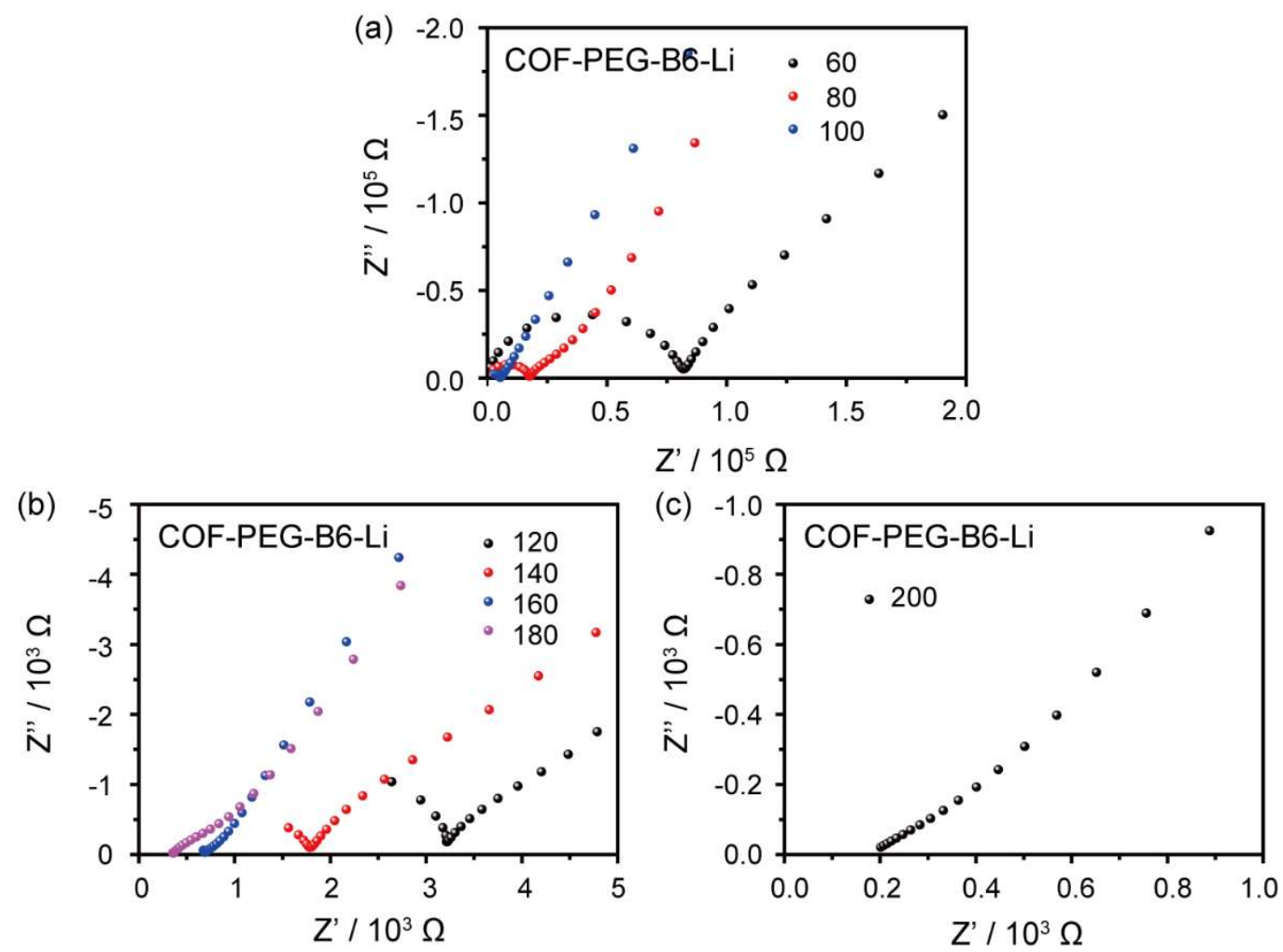

Fig. S14 Nyquist plots of COF-PEG-B6-Li (a) from $60{ }^{\circ} \mathrm{C}$ to $100{ }^{\circ} \mathrm{C}$, (b) from $120{ }^{\circ} \mathrm{C}$ to $200{ }^{\circ} \mathrm{C}$ and (c) at $200{ }^{\circ} \mathrm{C}$.

\subsection{Activation energy and transference number}

(a)

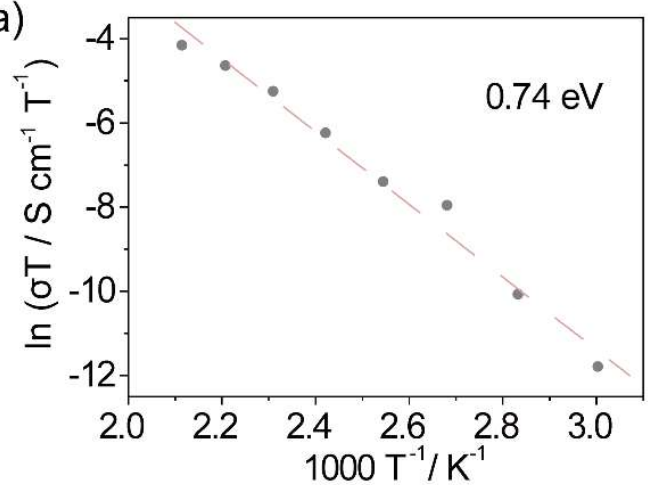

(b)

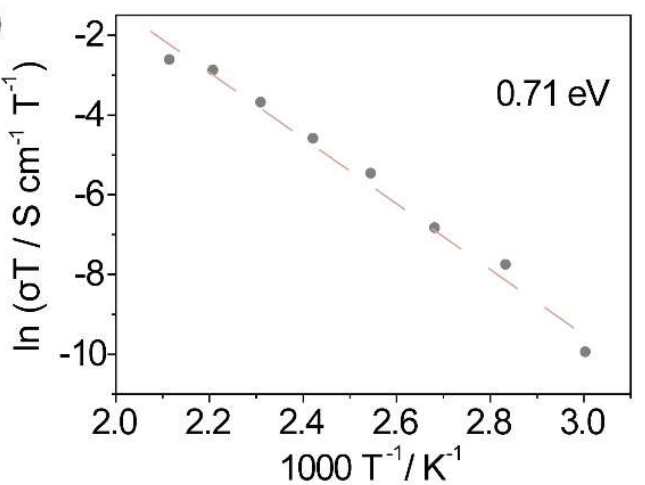

Fig. S15 Calculation of ionic conducting activation energy for (a) COF-PEG-B1-Li and (b) for COF-PEG-B3-Li. 


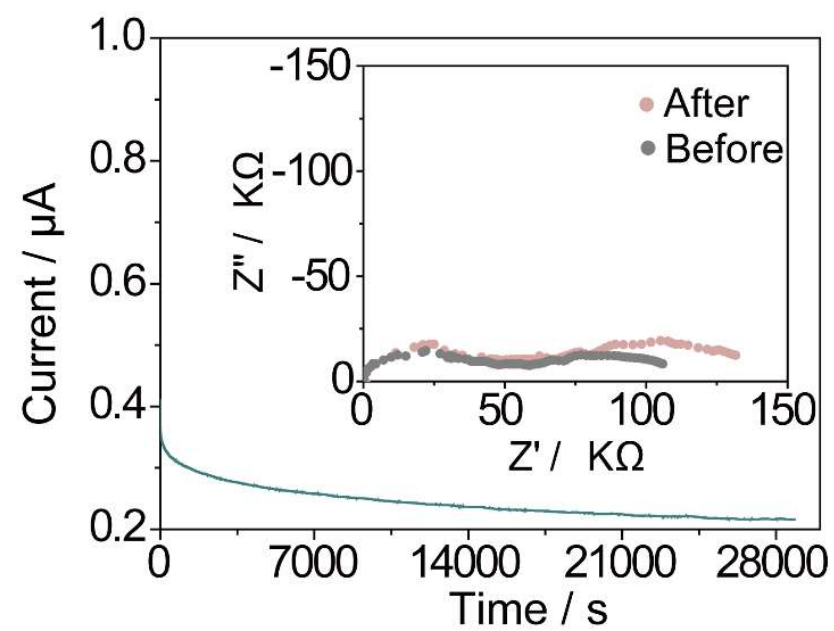

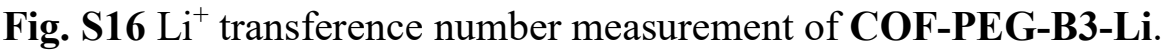

3.5 Full cell electrochemical performance tests

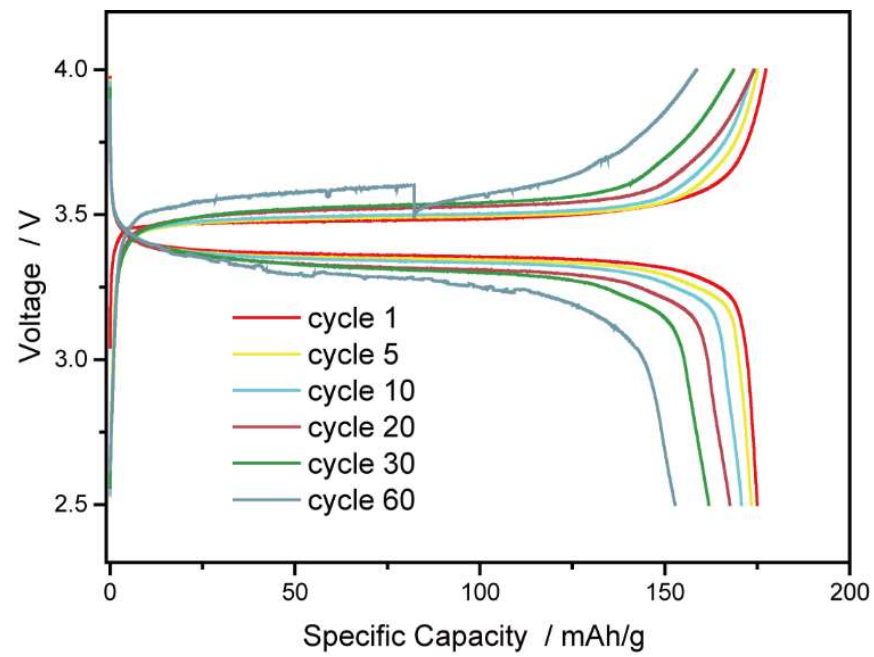

Fig. S17 Charge-discharge curves at various cycle of $\mathrm{LiFePO}_{4}|\mathbf{C O F}-\mathbf{P E G}-\mathbf{B 6}-\mathbf{L i}| \mathrm{Li}$ full cell cycled between $2.5 \mathrm{~V}$ and $4 \mathrm{~V}$ at $100{ }^{\circ} \mathrm{C}$.

\subsection{TEM images of COF-PEG-B1}

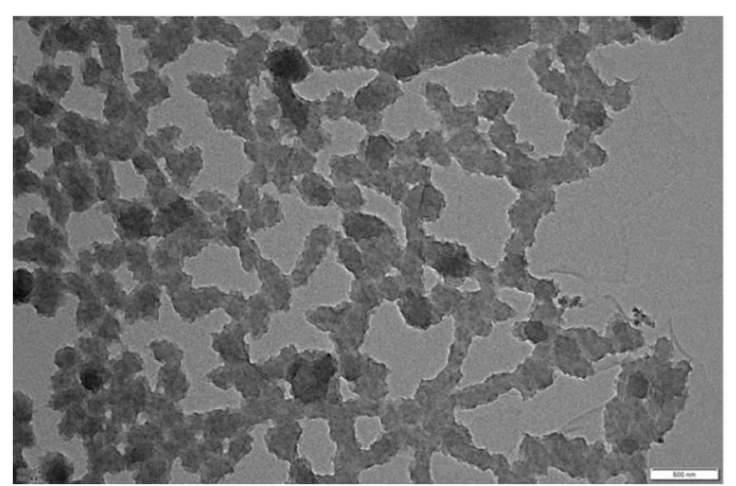

Fig. S18 TEM images of COF-PEG-B1 powders. 
3.7 NMR spectra of COFs
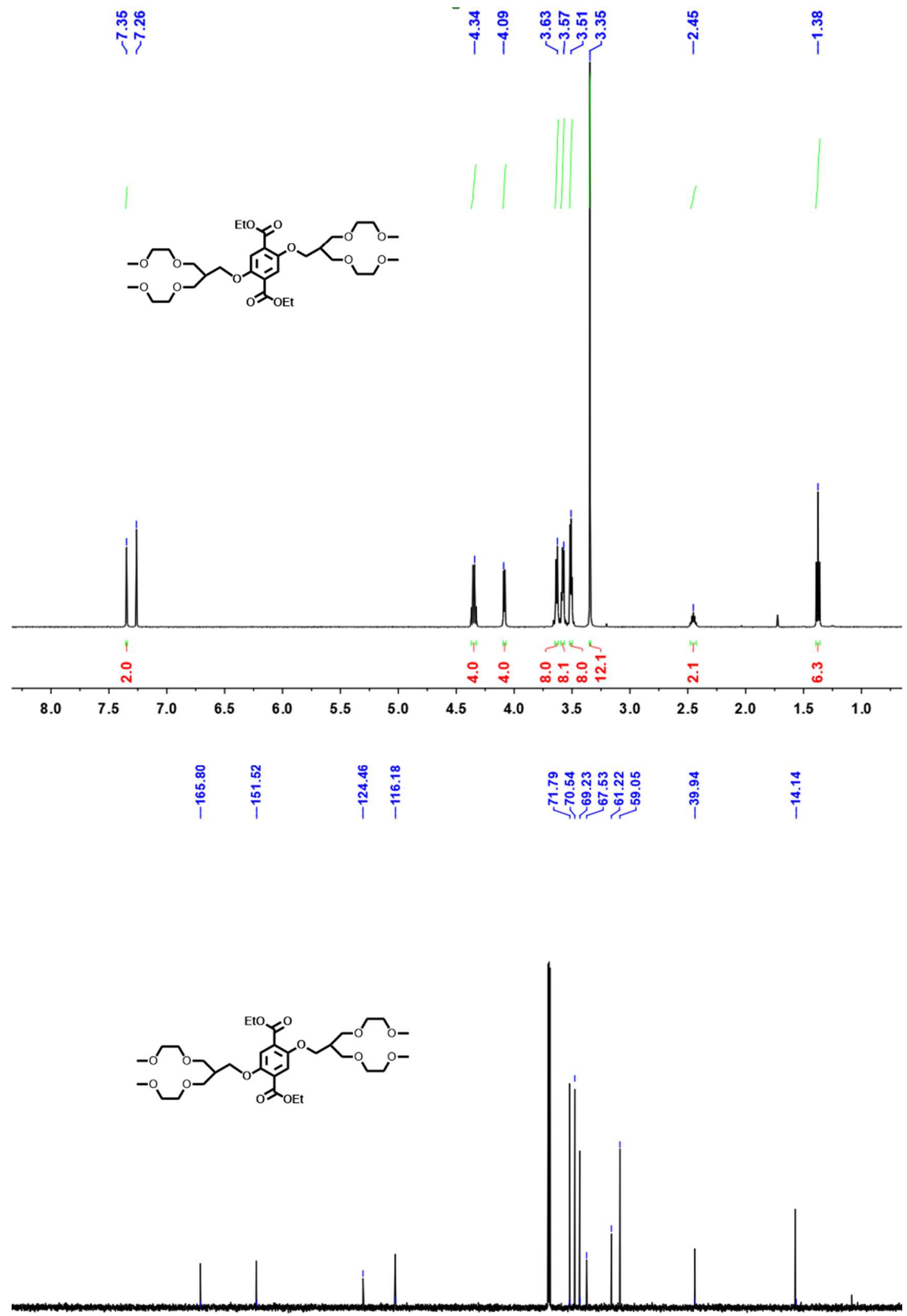

$\begin{array}{llllllllllllllllllllllllllll}210 & 200 & 190 & 180 & 170 & 160 & 150 & 140 & 130 & 120 & 110 & 100 & 90 & 80 & 70 & 60 & 50 & 40 & 30 & 20 & 10 & 0 & -10\end{array}$ Fig. S19 ${ }^{1} \mathrm{H}$ and ${ }^{13} \mathrm{C}$ date of PEG-B1-OEt. 

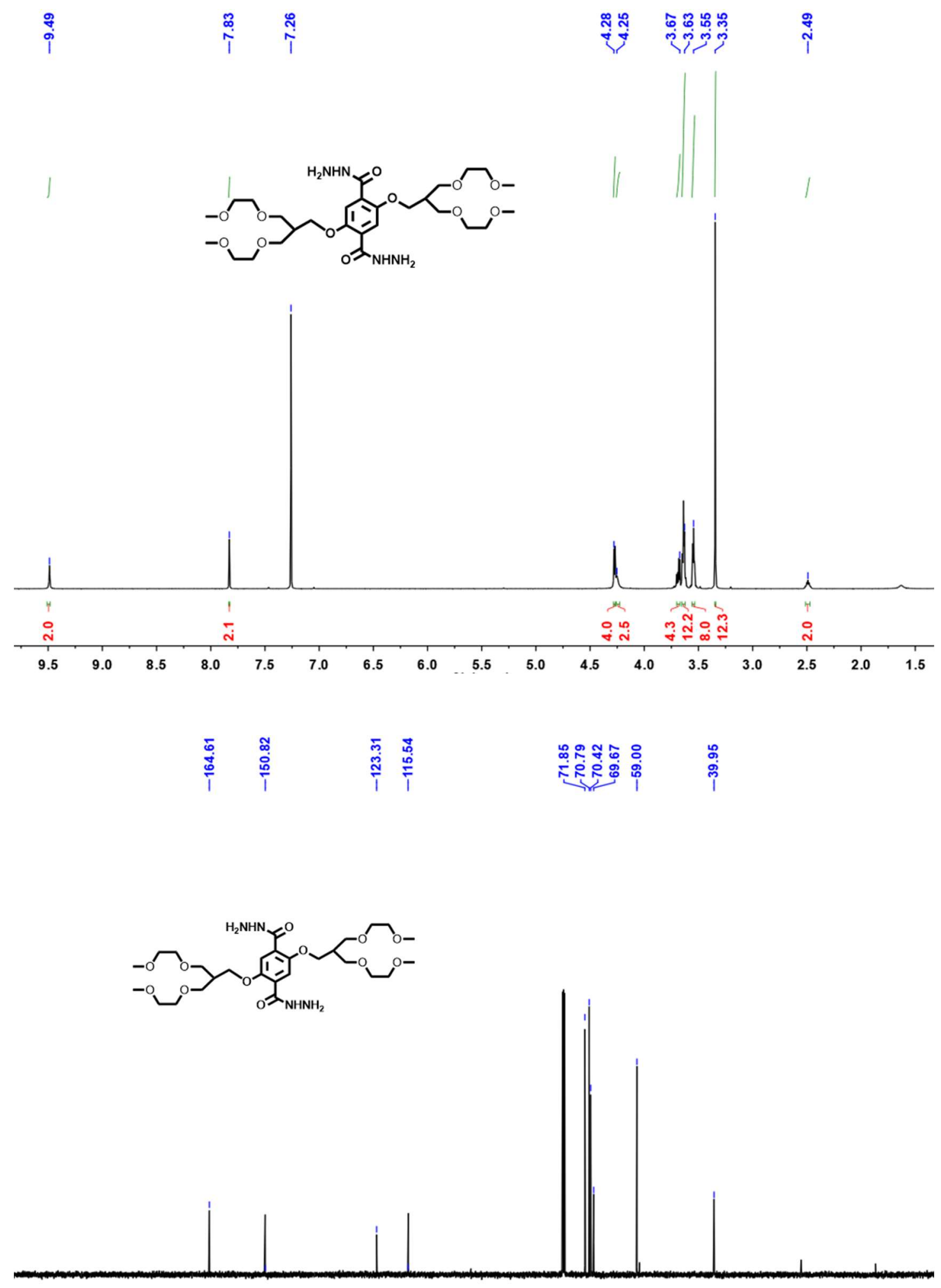

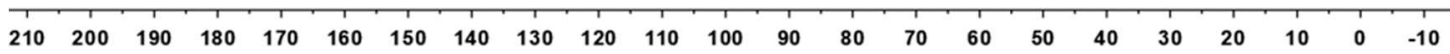

Fig. S20 ${ }^{1} \mathrm{H}$ and ${ }^{13} \mathrm{C}$ date of PEG-B1-NHNH2. 


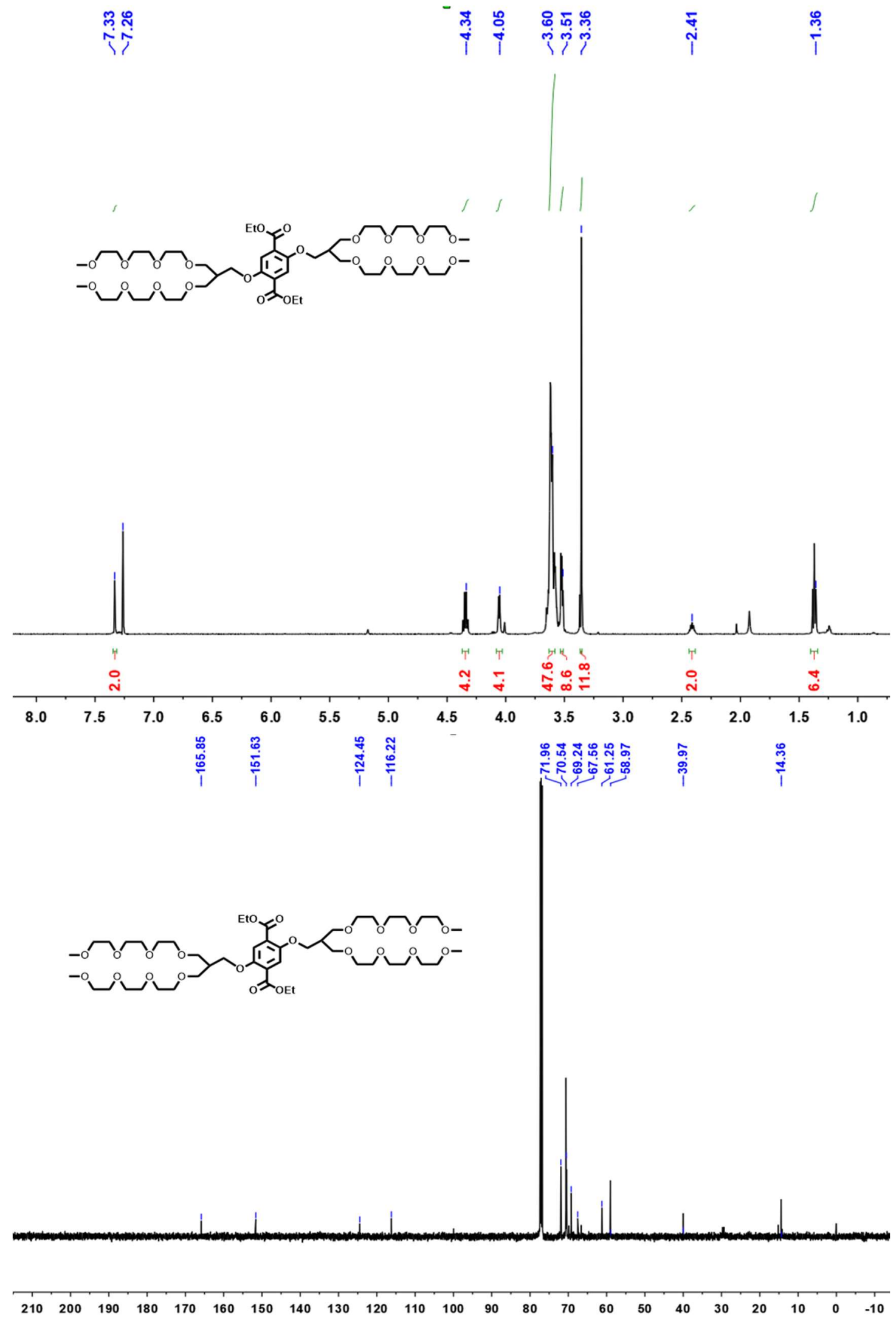

Fig. S21 ${ }^{1} \mathrm{H}$ and ${ }^{13} \mathrm{C}$ date of PEG-B3-OEt. 

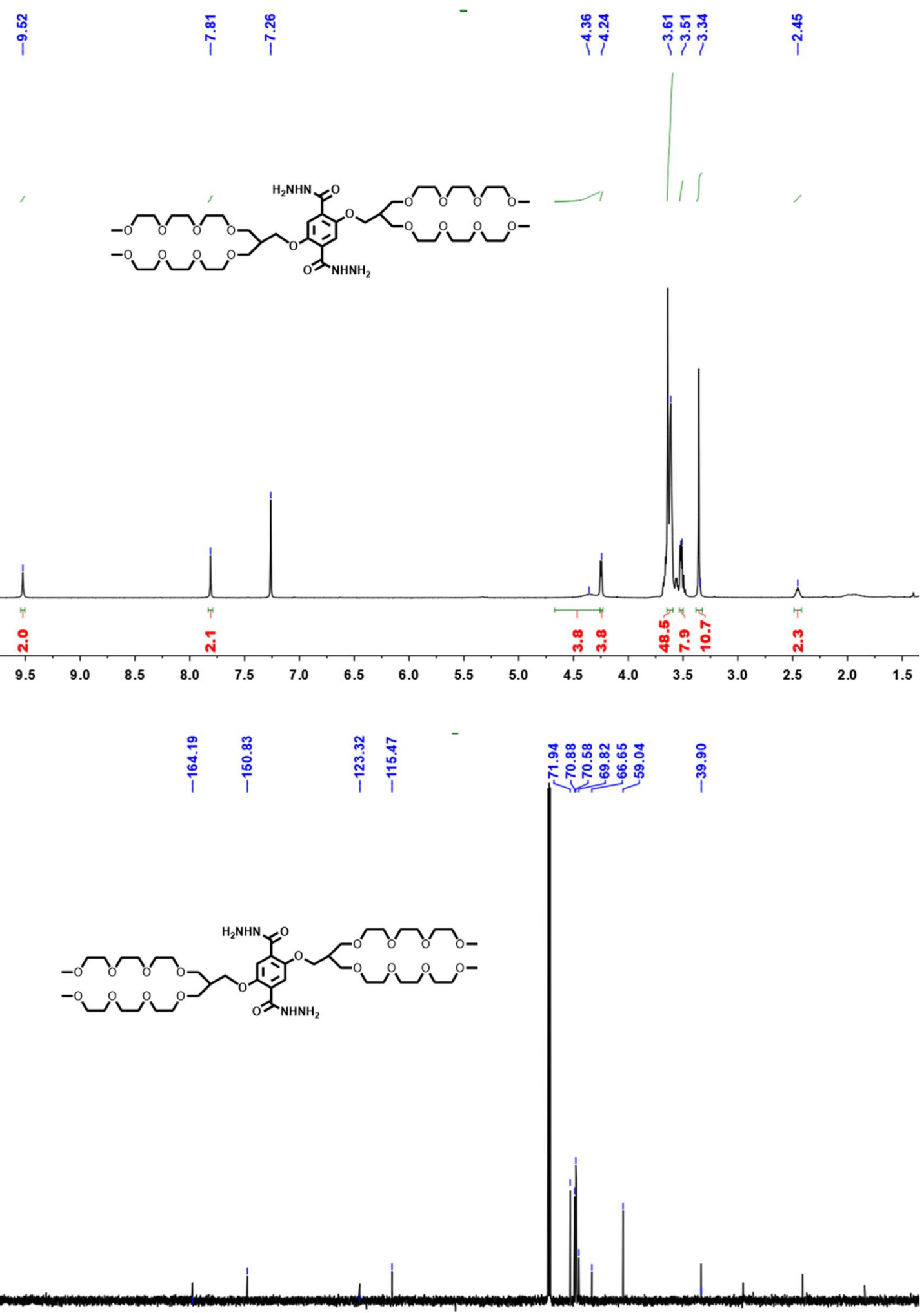

$\begin{array}{lllllllllllllllllllllllllll}1 & 210 & 200 & 190 & 180 & 170 & 160 & 150 & 140 & 130 & 120 & 110 & 100 & 90 & 80 & 70 & 60 & 50 & 40 & 30 & 20 & 10 & 0 & -10\end{array}$

Fig. S22 ${ }^{1} \mathrm{H}$ and ${ }^{13} \mathrm{C}$ date of PEG-B3-NHNH2. 


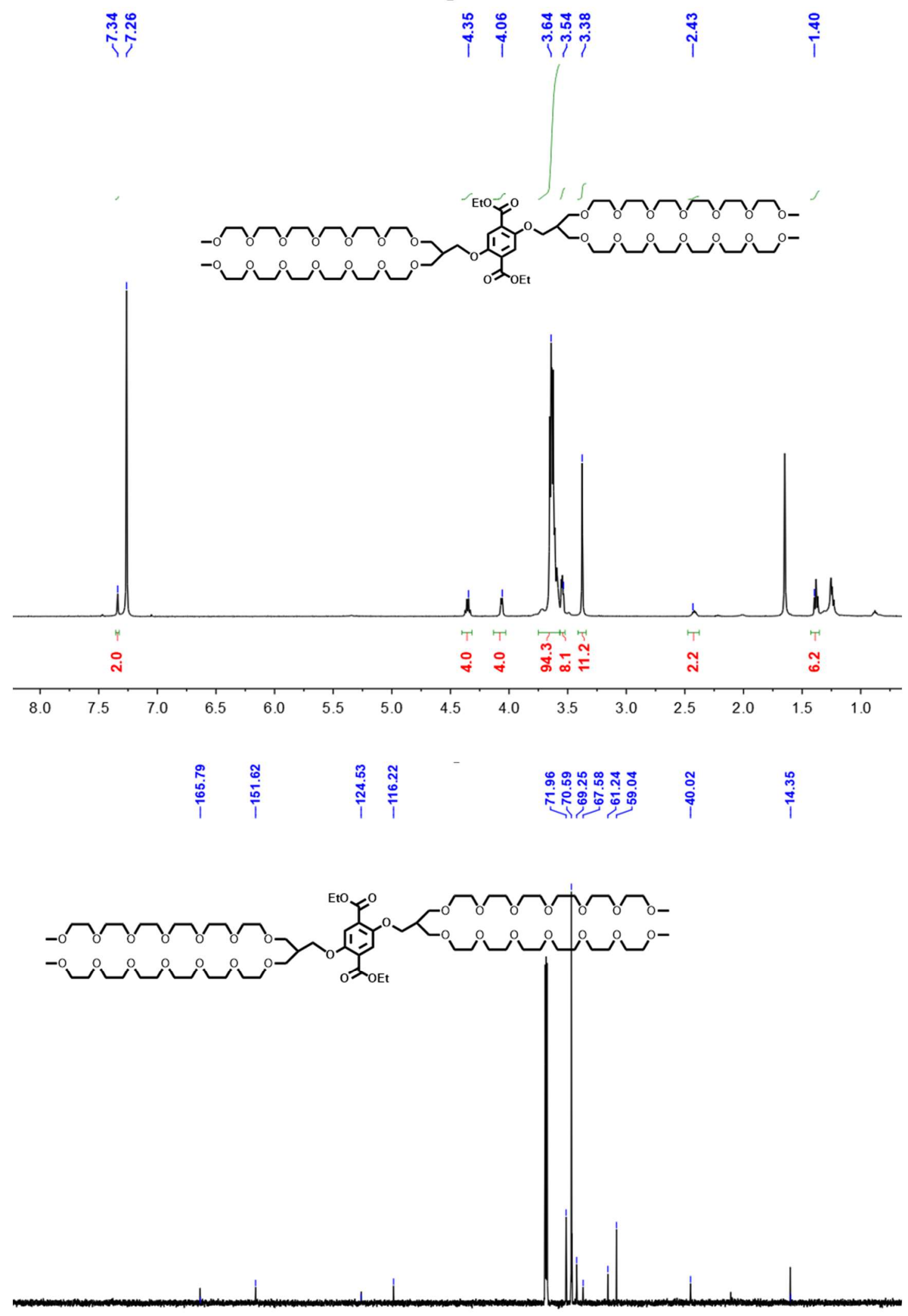

$\begin{array}{llllllllllllllllllllllll}210 & 200 & 190 & 180 & 170 & 160 & 150 & 140 & 130 & 120 & 110 & 100 & 90 & 80 & 70 & 60 & 50 & 40 & 30 & 20 & 10 & 0 & -10\end{array}$

Fig. S23 ${ }^{1} \mathrm{H}$ and ${ }^{13} \mathrm{C}$ date of PEG-B6-OEt. 


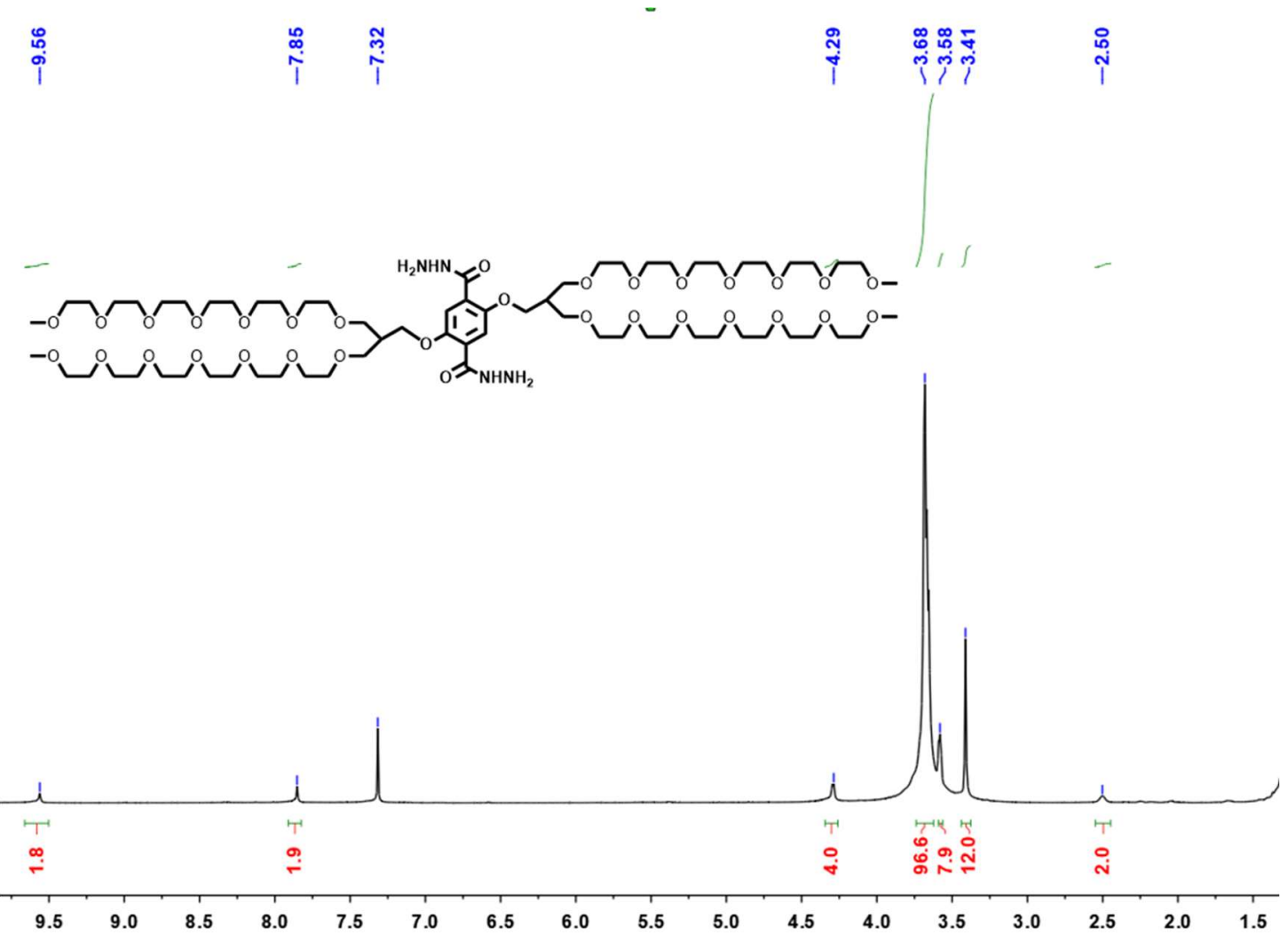

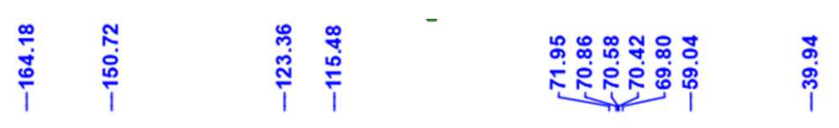
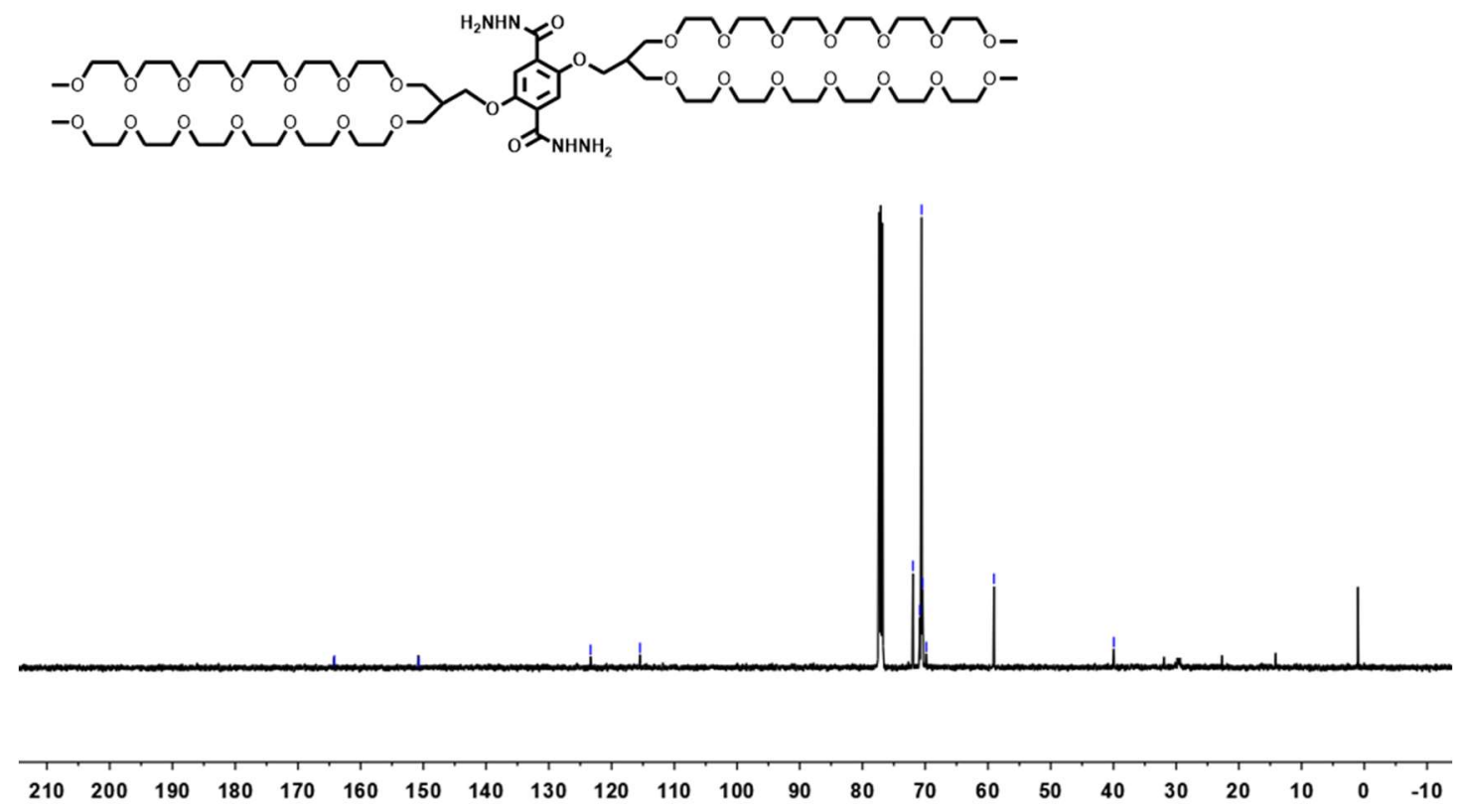

Fig. S24 ${ }^{1} \mathrm{H}$ and ${ }^{13} \mathrm{C}$ date of PEG-B6-NHNH2. 


\section{References:}

1. X. X. Chen, Z. J. Zhang, Z. C. Ding, J. Liu, L.X. Wang. Angew. Chem. Int. Ed. 2016, 55, 10153-10524

2. J. Y. Z. Wu, L. Y. You, L. Lan, H. J. Lee, S. T. Chaudhry, R. Li, J. X. Cheng, J. G. Mei. Adv. Mater. 2017, 29, 173403

3. G. Zhang, Y. L. Hong, Y. Nishiyama, S. Bai, S. Kitagawa, S. Horike. J. Am. Chem. Soc. 2019, 141, 1227-1234.

4. Materials Studio; Accelrys: San Diego. 